\title{
Assédio moral nos ambientes corporativos
}

\author{
Mobbing in corporation environments
}

Yumara Lúcia Vasconcelos ${ }^{1}$

Universidade Federal Rural de Pernambuco / Departamento de Administração, Recife - PE, Brasil

\begin{abstract}
Resumo
Esse artigo teve como objetivo caracterizar o assédio moral nos ambientes corporativos à luz do paradigma conceitual do que se concebe como "dignidade humana" e violação do princípio jurídico da boa-fé. Especificamente, visou identificar padrões na argumentação jurídica e no enquadramento de práticas nocivas à saúde mental do trabalhador. $O$ estudo, de natureza qualitativa, tomou por base o estudo de situações jurídicas, orientando-se pela demanda por definição e caracterização da prática assediadora no âmbito organizacional e dos limites do conceito da dignidade humana. Como principal resultado, o estudo colocou em contraste a necessidade de contextualização do fato propulsor da denúncia e caracterização do assédio, sem olvidar a relevância do significado ou sentido atribuído pelo indivíduo ao fenômeno analisado.
\end{abstract}

Palavras-chave: Assédio moral. Dignidade humana. Identidade.

\begin{abstract}
This study aimed to characterize the mobbing in corporation environments in the light of the conceptual paradigm of what is conceived as 'human dignity' and breach of the principle of good faith. Specifically, it aimed to identify patterns in legal arguments and framing harmful practices to mental health worker. The study, qualitative, was based on the study of legal situations, guided definition of demand and characterization of insistence practice in organizational scope and the limits of the concept of human dignity. As a main result, the study put in contrast the need for contextualization of propellant fact of the complaint and characterization of mobbing, without forgetting the importance of meaning or sense given by the individual to the phenomenon analyzed.
\end{abstract}

Keywords: Mobbing. Human dignity. Identity.

\section{Introdução}

O assédio moral tem integrado a agenda dos debates corporativos, visando definir os limites de atuação do indivíduo na organização, considerando os princípios garantidores dos direitos humanos. Os primeiros estudos datam da década de 1980, todos realizados em países escandinavos. Estudos quantitativos, o objetivo desses trabalhos consistia em relacionar condutas e consequências relacionadas no ambiente laboral. Essa produção científica inicial ensejou novas pesquisas em todo o mundo sob recortes e delimitações diversas; em geral, com o intuito de compreender o fenômeno e seus mecanismos de incidência. Atualmente, os trabalhos estão mais voltados para a identificação das possíveis origens da conduta e o empreendimento de soluções preventivas (HIRIGOYEN, 2012).

Artigo recebido em 14 de dezembro de 2014 e aceito para publicação em 7 de maio de 2015.

\section{DOI: http://dx.doi.org/10.1590/1679-395141446}

${ }^{1}$ Doutora em Administração pela Universidade Federal da Bahia/UFBA; Professora adjunta da Universidade Federal Rural de Pernambuco no Departamento de Administração e Programa de Pós-graduação em Controladoria/PPGC. Endereço: Rua Dom Manuel de Medeiros, s/n - Dois Irmãos, CEP 52171-900, Recife - PE, Brasil. E-mail: yumaravasconcelos@gmail.com 
No Brasil, os trabalhos de Barreto (2003) e de Freitas, Heloani, Barreto (2008) têm grande destaque, sendo referenciados em diferentes estudos como marco dessa produção científica. Em nível internacional destacamse as contribuições de Einarsen (2005), Leymann (1990) e Hirigoyen (2012; 2013a; 2013b; 2014).

O assédio moral é definido como uma modalidade de agressão psicológica, independente do meio utilizado (textos, postagens nas redes sociais, e-mails, gestos e atitudes). No ambiente de trabalho, essa agressão, de caráter continuado, expõe o indivíduo a situações humilhantes e, por isso, constrangedoras do ponto de vista social. A iniciativa guarda, portanto, relação direta com o comportamento do indivíduo nas organizações e estilo da gestão (ALKIMIN, 2013; GUIMARAES e RIMOLI, 2006; NEGRI, 2011).

Não se trata de um fenômeno típico de países pouco desenvolvidos, posto que a incidência do comportamento não implica relação direta com o desenvolvimento econômico. Inclusive,

[...] os estudos realizados e as iniciativas adotadas advêm quase que exclusivamente dos países mais desenvolvidos, basicamente os europeus, Estados Unidos, Canadá, Japão, Austrália e Nova Zelândia, os quais possuem maiores recursos para investimentos em pesquisas desta natureza. (GUIMARAES e RIMOLI, 2006, p. 183)

Entretanto, a conduta parece ter origem nos abusos decorrentes da desigualdade (social, funcional, de gênero ou qualquer outra) e diversidade inerentes às formações coletivas. Paradoxalmente, o nível de escolaridade, natureza e porte das organizações parecem não influenciar o assédio moral (PADILHA, PICHLER e FAGUNDES, 2011).

$\mathrm{O}$ assédio praticado no âmbito profissional (relacionado, portanto, às relações de trabalho) interessa a diferentes campos, especialmente, à administração, ao direito, à psicologia, à medicina (do trabalho) e à sociologia. Na verdade, seu estudo interliga diferentes áreas (ALKIMIN, 2013; RUFINO, 2011).

Trata-se de um problema complexo e multifacetado, apresentando diferentes origens e variáveis facilitadoras, dentre as quais se destacam as mudanças verificadas no sistema produtivo (fator referenciado amplamente na literatura) (ALKIMIN, 2013; FREITAS, HELOANI e BARRETO, 2008). Todavia, advogase o ponto de vista de que a citada complexidade remete necessariamente à consideração de outras dimensões de análise.

Decerto, o assédio tem sido tratado de perspectivas distintas que o tem ressignificado ao longo dos anos, redefinindo e ensejando medidas preventivas, reconstruindo o sentido do trabalho na vida do indivíduo.

A competição interna e o individualismo extremado não podem ser justificados exclusivamente pelas características do modelo de produção. Desconsiderar outras leituras e olhares implica promover o esvaziamento de sentidos do problema e desumanizar uma patologia social.

Os fatores psicossociais compreendem o conjunto de condições presentes no ambiente de trabalho com potencial de afetar o bem-estar e a saúde do trabalhador, sua sociabilidade e produtividade (o que inclui, necessariamente, sentimentos e relacionamentos interpessoais). Esse entendimento norteou e justifica a organização estrutural deste artigo.

A prática do assédio moral corporativo consolida-se a partir de uma polaridade de influências, onde um polo "comanda" a relação e o outro "aceita" passivamente as coordenadas (temporariamente ou não), incitado por condicionantes diversos. Essa polaridade nem sempre é de natureza funcional, mas, indubitavelmente, cria uma hierarquia invisível, informal e não legitimada de poder. Por esse ângulo, o assédio no âmbito trabalhista também alcança indivíduos pertencentes a um mesmo nível hierárquico (assédio moral de linha ou horizontal). Não obstante se reconheça essa possibilidade, o assédio mais observado é o vertical, incidente sobre a mão-de-obra situada na base da hierarquia funcional. 
Independente da modalidade de assédio moral, a submissão por parte da vítima não implica necessariamente a aceitação autêntica (permanente), mas, sim, circunstancial, o que gera propensão à reação de denúncia e providências jurídicas futuras.

Sabe-se que cabe ao empregador ensejar um ambiente de trabalho saudável, respeitando os direitos humanos, as diretivas constantes na legislação trabalhista, convenções, acordos coletivos e costumes consagrados. Essa orientação implica tratar o assédio moral como uma cediça violação contratual na relação de trabalho, o que reclama respeito aos valores individuais de natureza material e subjetiva (moral).

A confiança é o ingrediente essencial de qualquer relação jurídica, conferindo transparência, predisposição e disponibilidade ao diálogo, visando à consecução das expectativas realizáveis, elaboradas pelas partes.

Na seara legal, a acepção moderna do conceito de boa-fé invoca: cooperação entre os agentes numa relação; respeito à confiança depositada; credibilidade; expectativa predita de comportamento (segundo os padrões preliminarmente estabelecidos); lealdade; honra aos compromissos e atendimento às disposições contratuais. Esses elementos compõem um paradigma de conduta moral, definidor de comportamentos socialmente aceitáveis.

Além do princípio da dignidade, o assédio moral no trabalho viola o princípio jurídico da boa-fé. O plástico conceito de moralidade está atrelado a um espectro de componentes subjetivos, a exemplo da dignidade humana.

Esse artigo objetiva, em nível geral, caracterizar o assédio moral nos ambientes corporativos, à luz do paradigma conceitual do que se concebe como "dignidade humana" e princípio da boa-fé. Especificamente, visa-se: a) identificar padrões na argumentação jurídica e no enquadramento de práticas nocivas à saúde mental do trabalhador; b) obter, à luz da revisão da literatura afim, a repercussão do assédio moral corporativo; c) compor, a partir do olhar dos trabalhos revisados e impressões de seus autores, os elementoschave definidores do conceito de dignidade humana.

O estudo orientou-se pela seguinte problematização: O que define e caracteriza a prática do assédio no âmbito organizacional? Complementarmente, apresentou respostas às indagações: Quais os limites do conceito da dignidade humana? E dos padrões de conduta gerencial? O referencial teórico foi estruturado sob a diretriz dessas questões, promovendo uma análise construída a partir das perspectivas do direito e da administração.

A motivação principal para a realização deste estudo, no enfoque proposto, foi a constatação de que, ao longo dos anos, o direito do trabalho foi alijado do estudo dos direitos humanos, apesar de tratar-se de um direito humano fundamental ao desenvolvimento do indivíduo. A complexidade e as consequências do fenômeno justificam, igualmente, a relevância de pesquisas do gênero e tornam o tema fecundo em delimitações e ênfases.

\section{Referencial Teórico}

A revisão de literatura foi organizada a partir dos argumentos-chave que explicam os resultados obtidos na pesquisa de campo realizada. As seções deste artigo foram preparadas conforme os objetivos propostos e de acordo com uma análise contextualizada e crítica da produção revisada.

\section{Assédio moral: conceito, caracterização e espécies.}

O assédio moral não é um fenômeno recente. Todavia, ganhou destaque em razão da abordagem humanística na principiologia jurídica, cujo marco foi a promulgação da Constituição Federal de 1988. 
Na França, existe jurisprudência relacionada ao tema, vinculada às relações de trabalho, desde 1960. Na Alemanha, Itália, Suécia, EUA e Austrália, a prática já é reconhecida como delito. Na Noruega há previsão da conduta na Lei do trabalho, naquelas que tratam, respectivamente, da igualdade de gênero e da discriminação.

No mundo do trabalho, o assédio moral configura-se como o emprego deliberado de poder ou influência psicológica, na forma de ameaça contra terceiros, com potencial de causar lesões, danos psicológicos, privações, ou mesmo transtornos ao desenvolvimento psicofísico do indivíduo (ALKIMIN, 2013; CUNICO, 2014; THOME, 2011; WYZYKOWSKI, BARROS e PAMPLONA FILHO, 2014).

Guimarães e Rimoli (2006) denominam os efeitos da prática sobre a saúde do indivíduo como síndrome psicossocial multidimensional. Os autores justificam a denominação:

- síndrome, uma vez que comporta sintomas físicos e psíquicos peculiares e prontamente diagnosticáveis que, em conjunto, definem uma patologia, apesar da dificuldade de se obter uma configuração típica;

- psicossocial, porque as disfunções decorrentes afetam o indivíduo e o ambiente social que o mesmo integra; e

- multidimensional, porque é multifacetado e multicausal, afetando o todo organizacional, independente de nível hierárquico, com repercussão fora do meio laboral.

De fato, na atualidade, o fenômeno é colocado no mesmo nível de outras enfermidades ocupacionais de impacto (RODRIGUES, 2009). Trata-se, portanto, de um comportamento irracional e humanamente nocivo (do ponto de vista das consequências). Entende-se como comportamento racional aquele esperado de uma pessoa comum em determinadas circunstâncias. A irracionalidade comportamental se desvia dessa expectativa média, apresentando dissonância em relação ao padrão. Por esse ponto de vista, o assédio moral não se enquadra como comportamento racional ou mesmo moralmente aceitável.

Conflito pessoal assimétrico no ambiente laboral, individual ou em bloco, a prática leva a um processo gradativo e inconsciente de destruição psicológica, que se dá implicitamente por meio de palavras, gestos, alusões hostis e mascaradas, com mensagens subliminares carregadas de agressividade, atentando contra a dignidade do indivíduo (SANTANDER, 2007).

Os autores revisados apontam como nascedouro do fenômeno as mudanças verificadas na estrutura produtiva das organizações, hierarquias funcionais rígidas, pressões exercidas pelas iniciativas de terceirização e subcontratação, contornos políticos do neoliberalismo, competição acirrada, globalização, necessidade de redução dos custos trabalhistas, rotinas voltadas para aumentar os níveis de demanda e modernização das relações de trabalho (ALKIMIN, 2013; FERREIRA, MENDES, CALGARO et al., 2006; FREIRE, 2009).

O cotidiano dos relacionamentos laborais revela a necessidade de se considerar outros componentes determinantes da conduta, a exemplo da carga emocional, das expectativas profissionais, frustrações e da história de vida do indivíduo na relação com seus pares; elementos que determinam o modo como o mundo é interpretado (GUIMARAES, RIMOLI, 2006).

Percebe-se o assédio moral como resultante da sinergia de causas, perpassando as seguintes: dimensões do ser e estar (pessoa), interpessoal, macroambiental e organizacional.

Eleger como possíveis causas do assédio apenas variáveis exógenas implica negar sua atividade social e autonomia de escolha (livre arbítrio), além de simplificar um problema por natureza complexo.

O assédio moral promove a degradação do ambiente de trabalho, comprometendo a qualidade de vida das pessoas na organização, afetando o ânimo pessoal. Em consequência, cresce a rotatividade funcional, os custos de entrada e saída, e ainda os gastos com reintegração (CUNICO, 2014). 
O interesse das corporações pelo tema não se configura como iniciativa meramente altruísta, tendo em vista a magnitude da repercussão do problema sobre o seu desempenho econômico.

$\mathrm{Na}$ literatura internacional são utilizadas diferentes denominações: psicoterrorismo (Portugal), mobbing e bullying (países de língua inglesa), mobbing (países de língua germânica), harcèlement moral (França e Bélgica) e acoso moral, acoso institucional (Espanha) (THOME, 2011).

Leymann (1990) restringe o mobbing àquelas ocorrências com adultos e o bullying, àquelas com crianças.

A semântica atribuída a cada expressão reflete a maneira como o fenômeno é atribuído e interpretado culturalmente.

Modalidades de abuso interpessoal, o mobbing é definido como um fenômeno sistemático e interativo que pode ocorrer em todos os tipos de organização, atingindo a dignidade e a integridade psíquica do indivíduo, resultando em vitimização (DUFFY e SPERRY, 2012).

Duffy e Sperry (2012) destacam que a expressão "vítima" é usualmente evitada, sendo considerada politicamente incorreta em algumas culturas.

Sánchez (2003) usa a expressão "destruição anímica" (da alma) para fazer referência à magnitude do fenômeno na intimidade da pessoa.

Apesar do crescimento do número de trabalhos, permanece a lacuna relativa à homogeneidade terminológica, o que pode ser justificado pelo espectro de situações que comporta o fenômeno, produzindo configurações distintas.

A intensa produção nos últimos 10 anos foi catalisada pela frequência de situações de violência psicológica, todavia a prática assediante não é recente (LORENTE, 2005). Nas iniciativas de justificação, a II Guerra Mundial, em um legado nefasto, banalizou práticas abusivas de massa que se estenderam a outros ambientes em escalas menores.

O continuado comportamento malfazejo é constatado, usualmente, dentro de uma realidade particular de submissão hierárquica, não obstante existam outras formas.

Um ponto interessante das discussões acerca do assédio moral nas relações de trabalho é que o tratamento temático toma por base o princípio jurídico da dignidade humana, que implica um olhar social igualitário. Ocorre que, nas relações de trabalho, a existência de um contrato de trabalho promove uma relação de sujeição de uma pessoa (hipossuficiente) em relação à outra dotada de poder ou influência.

A caracterização do assédio moral não é unânime entre os autores, mas compreende usualmente: comportamento impertinente e socialmente censurável (ofensivo), por ação ou omissão, seja ela culposa ou dolosa; dano psíquico; frequência apreciável (série de atos), tendo em vista que contratos de curta duração dificultam a identificação da conduta reiterada; intervalos curtos de repetição (em alguns casos até gradação); pouco tempo para recuperação entre uma e outra investida; intensidade de violência psicológica aplicada de modo sistemático e prolongado; duração ou periodicidade; intencionalidade e premeditação (ALKIMIN, 2013; CASTRO, 2014; DALLENGRAVE JÚNIOR, 2012; HIRIGOYEN, 2013a; 2014; LORENTE, 2005; ROJO e CERVERA, 2005; RUFINO, 2011; SCHLINDWEIN, 2013; THOME, 2011; VILELLA, 2012; WYZYKOWSKI, BARROS e PAMPLONA FILHO, 2014).

De fato, o assédio se verifica por meio de ações em série (fato unitário), que em conjunto produzem microtraumatismos, os quais, somados, configuram o dano. Significa dizer que o assédio moral é gradativo, processual, pressupondo investidas continuadas por parte do assediador, esvaziando o sentido atribuído à experiência social do trabalho (figura 1). 
Apesar da vasta produção científica, que apresenta e discute as características do assédio moral, as dificuldades de ordem prática permanecem, especialmente, nos casos onde a intenção não resta configurada no caso concreto.

Admite-se nessa pesquisa que a pessoalidade e a intenção distinguem o assédio moral de outras modalidades de agressão psicológica. Essa estratificação, todavia, não isenta o assediador de sua responsabilidade civil e penal. Nessa perspectiva, exclui-se a culpa como elemento de caracterização da conduta, embora, referenciada na literatura.

O dolo é o elo que conecta objetivamente assediado e assediador. Nessa concepção, confrontando o entendimento majoritário no campo, nem todo assédio organizacional é necessariamente moral. $\mathrm{O}$ assédio organizacional é configurado quando a prática serve aos propósitos de lucro (motivação exclusiva). O fato das consequências serem "morais" não desnatura essa modalidade de assédio. O assédio corporativo puro é apessoal.

Desse modo, compreende-se como fatores-chave da prática: o dolo (intenção dirigida a alguém ou grupo), a pessoalidade, o objetivo lesivo, a premeditação, a processualidade e a lesão ou dano decorrente (nexo causal).

Figura 1

\section{Progressão dos fatos unitários e a culminância do dano}

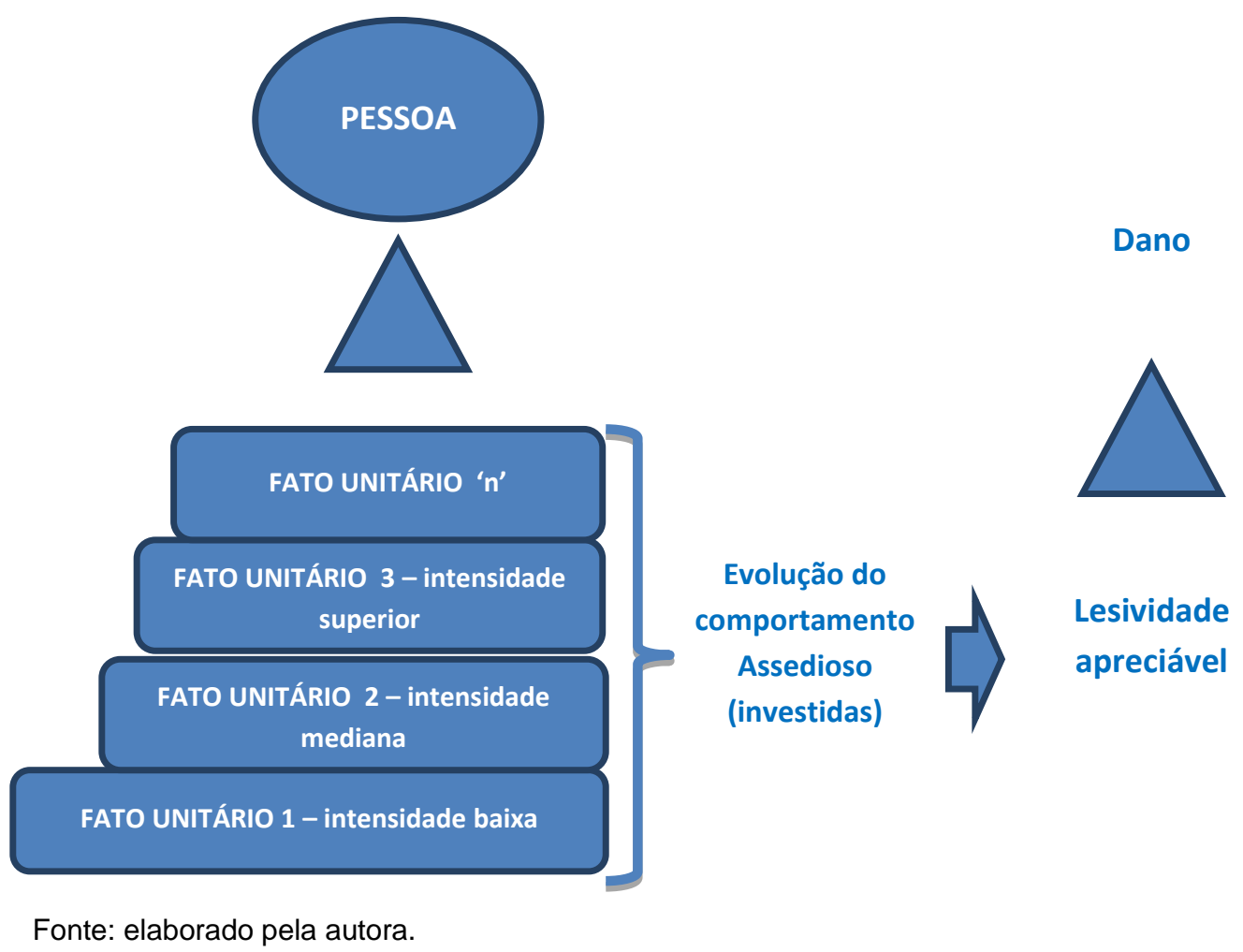

Em geral, o assédio inicia com agressões de intensidade baixa, evoluindo gradativamente segundo a vulnerabilidade da vítima, o alcance da conivência ativa e passiva, bem como, o efeito patrocinado pelas investidas. Ao empreender essa estratégia, o assediador revela cautela e senso de autopreservação, testando e apurando sua abordagem. 
Leymann (1990) destacou em seu estudo como elementos definidores do assédio a periodicidade (seis meses ou mais) e a frequência (no mínimo, duas vezes por semana). Todavia, a parametrização objetiva reclama reflexão, tendo em vista a diversidade de interpretações aplicáveis ao caso concreto.

A regularidade parece ter importância secundária relativamente à análise das estratégias engendradas pelo assediador e o impacto decorrente.

Os propósitos do agressor são variados: comprometer a imagem da vítima, desacreditando-a; sabotar processos organizacionais; perturbar o exercício profissional do individuo ou mesmo do grupo; lograr êxito em competições; alcançar satisfação pessoal; minar a rede de relacionamentos do assediado, deixando-o fragilizado e vulnerável a novas incidências, entre outros (HIRIGOYEN, 2012). Nesse intento, geralmente, isola socialmente a vítima para coibir eventual reação e minar as possibilidades de comunicação.

Para que seja configurado o assédio moral numa relação de emprego é fundamental a identificação e caracterização do ato agressor (incidência e repetição, conduta continuada) e o dano à dignidade do trabalhador (prejuízo de ordem psíquico-emocional) (DALLENGRAVE JÚNIOR, 2012; VEIGA, 2011).

O assédio, essencialmente moral ou corporativo puro, pode ser direcionado a um ou a mais empregados, o que enseja sua categorização em individual e coletivo (ou estratégico). Esse último, geralmente relacionado a interesses econômicos (HAAK e ABAL, 2014).

A doutrina também estabelece diferença entre o assédio moral interpessoal e organizacional (coletivo) (VILELLA, 2012). Deve ser acrescentado ainda o assédio intergrupos. O assédio moral interpessoal alcança o indivíduo. $\mathrm{O}$ assédio organizacional ou coletivo é, muitas vezes, mascarado por referências a políticas empresariais ou, mesmo, estratégias ditas modernas, igualmente aviltantes e cerceadoras das liberdades do indivíduo no ambiente de trabalho. A injúria, o medo, a emoção, a fragilidade e o stress são manipulados na consecução de atos constrangedores. Quanto ao assédio intergrupos, este tem origem, paradoxalmente, na convergência de identidades e coalizão de interesses de grupos distintos.

Os conflitos evoluem a partir das diferenças, incitadas por um espectro de motivos: inclinações políticas divergentes; imaturidade pessoal; aspirações individuais de poder e influência; intolerância; preconceito; insatisfação profissional; vaidade; infelicidade; objetivos profissionais em rota de colisão; individualismo exacerbado e questões pessoais diversas, entre outros.

Os estudos acenam para outra categorização do assédio, que toma como parâmetros os atores envolvidos na prática e o sentido do ato ofensivo.

A figura 2 ilustra as modalidades de assédio moral no universo corporativo, segundo essa parametrização. 
Figura 2

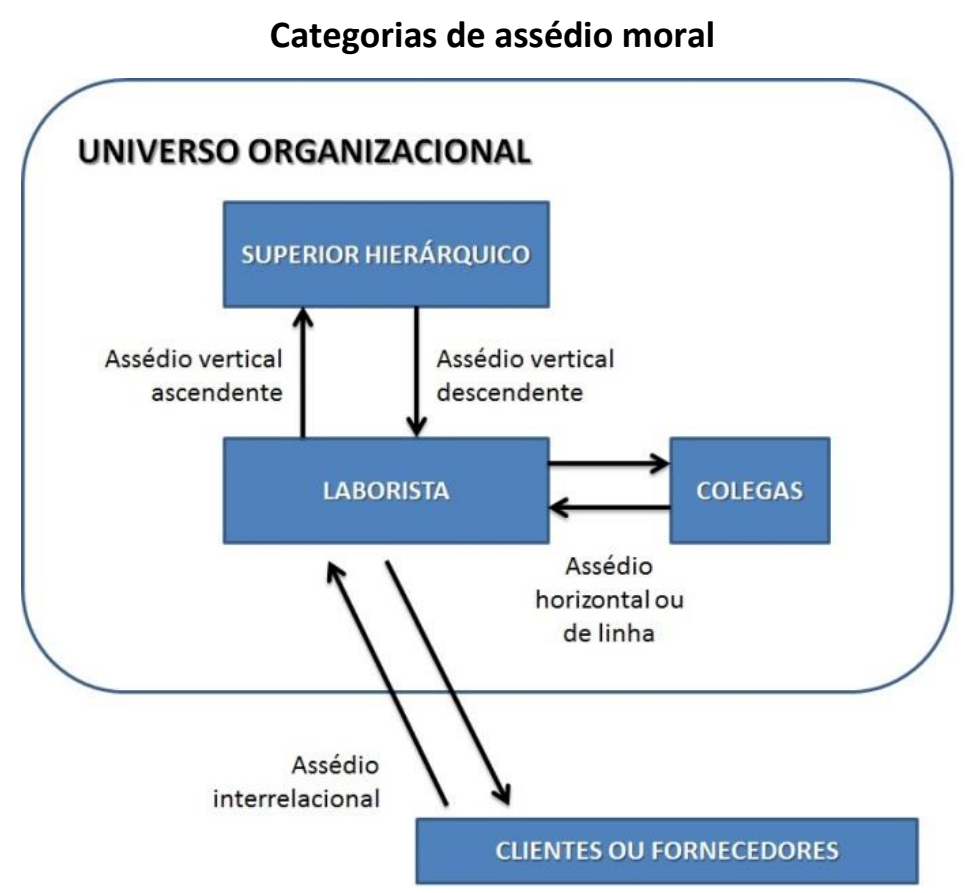

Fonte: elaborado pela autora.

$\mathrm{O}$ assédio vertical descendente é iniciativa de um superior na hierarquia funcional, atingindo um ou mais laboristas. Nessa modalidade de assédio, existe um condicionamento quid pro quo (que significa "isso por aquilo"), ou seja, submissão pela manutenção do posto de trabalho. Já o assédio vertical ascendente parte de um ou mais subordinados, alcançando um ente superior nessa mesma hierarquia (CASTRO, 2014; FERREIRA, MENDES, CALGARO et al., 2006). Esse último é comum em disputas por promoções e cargos, onde aqueles não contemplados pela oportunidade de ascensão oferecem naturalmente resistência às decisões do promovido ou empossado. Em alguns casos, os colegas se organizam para sabotar a gestão do outro.

Os boicotes são formas de assédio ascendente. Essa modalidade pode tornar a organização um sistema autofágico com grande potencial lesivo, afetando sua longevidade a médio e a longo prazos.

O assédio moral de linha, denominado horizontal, se verifica entre colegas do mesmo nível na convivência no ambiente laboral. As motivações para esse tipo de assédio são variadas, podendo esconder atitudes homofóbicas, preconceitos de gênero, inclusive, aqueles de natureza racial e de classe social.

Foi denominado assédio inter-relacional aquele formato em que o agente ativo no processo assediante não integra o universo organizativo ou funcional da corporação (clientes-funcionários, fornecedores-clientes).

Os mecanismos de incidência se apresentam de diferentes formas: manifestação de desdém; alusões pejorativas (especialmente, a qualidades físicas); postagens nas redes sociais e e-mails que denigram a imagem do trabalhador; iniciativas de marginalização; comentários depreciativos; discriminação de qualquer natureza e apelidos vexatórios, entre outros.

As estratégias destrutivas são variadas. $\mathrm{O}$ modus e a intensidade parecem guardar relação direta com o objetivo da abordagem assediante.

A etiologia da responsabilização civil orienta a seguinte composição: o desrespeito a uma norma preexistente ou aos princípios jurídicos, o dano e o nexo de causalidade entre ambos. 
A intenção e o estabelecimento de uma relação de causalidade entre a antijuridicidade da conduta e o dano gerado constituem pontos fundamentais.

Essa correlação biunívoca ocasiona à parte ré o compromisso de indenizar (reparação) numa eventual ação por dano moral. $\mathrm{O}$ fato de o assédio ser praticado por empregado investido de cargo não exime o empregador de responsabilidade civil, uma vez que responderá pelos atos de seu preposto, que no caso empreendeu a sequência de atos degradantes (BRASIL, 2002, fundamento: art. 932, III, do Código Civil). Inexiste previsão para os atenuantes dessa responsabilização, a exemplo de políticas de prevenção.

A ação trabalhista de rescisão indireta e de reparação civil por danos atinge naturalmente o empregador, cabendo a ele propor ação de regresso em relação ao assediante.

Essa característica reforça a necessidade de uma educação gerencial mais humanística e de se estudar os vetores ou fatores que determinam o comportamento das pessoas no ambiente de trabalho, fontes e motivos mais eficazes do prazer no exercício laboral (no plano coletivo ou individual).

\section{Responsabilidade social do empregador}

O empregador deve propiciar um ambiente laboral adequado à convivência social harmônica, cultivando a civilidade nas relações profissionais, o que usualmente é empreendido:

- estimulando condutas éticas e transparentes (à luz de códigos de ética);

- implementando políticas de relacionamento interpessoal no ambiente de trabalho;

- elaborando políticas antiassédio;

- proibindo expressamente determinados comportamentos;

- formalizando meios de investigação e medidas punitivas cabíveis para eventuais ocorrências;

- criando espaços de convivência pessoal;

- incentivando práticas gerenciais baseadas na cooperação, interação, dádiva e solidariedade;

- extirpando a competição profissional predatória e improdutiva;

- ensejando mecanismos de controle e acompanhamento (canais de comunicação, ouvidoria e comissões de direitos humanos, entre outros);

- promovendo campanhas de conscientização;

- formando grupos de orientação e suporte dentro da própria organização;

- realizando dinâmicas de integração, visando aproximar as pessoas e estabelecer vínculos de afetividade (sentido fraternal), além de solucionar conflitos;

- coibindo comportamentos degradantes através da promoção de medidas pedagógicas;

- promovendo cursos voltados para o tema, dirigidos especialmente para gestores;

- aproximando-se dos sindicatos para, em parceria, implementar grupos de apoio e orientação, já que algumas pessoas se sentem mais à vontade para relatar tais problemas a membros de entidades de classe;

- estabelecendo diálogo franco e fraterno entre os pares, para ensejar o respeito às "liberdades" e a tolerância.

Cumpre ressaltar que existem limites à subordinação jurídica do trabalhador, que deve ter seus interesses privados e liberdades preservados (FERNANDES, 2008). 
As punições usualmente atribuídas ao assediador, quando ocorrem, apresentam graus variáveis, conforme a lesividade do ato, compreendendo desde advertência à rescisão contratual, podendo culminar em justa causa motivada por incontinência de conduta ou mau procedimento. Existem ainda as sanções pedagógicas.

Em face do exposto, recomenda-se ao gestor incluir nos processos de admissão, o procedimento de assinatura de termo de compromisso, disciplinando regras de condutas sociais, ao mesmo tempo em que o contrato de trabalho é firmado. A participação do sindicato da categoria na formulação desse termo confere maior alcance e respaldo político.

Embora o empregador tenha o direito, no exercício do poder diretivo, de apurar irregularidades cometidas por funcionários, esse processo deve respeitar limites. Assim, eventuais excessos configuram ilicitude, uma vez que violam direitos de personalidade. Esses direitos têm natureza privada, sendo inerentes e essenciais à pessoa em seu desenvolvimento (amplo sentido). Inclui proteção à honra, imagem, reputação, liberdade e intimidade. O assédio moral afronta esses direitos, extrapolando os limites do que se define como poder diretivo, o que justifica a crescente preocupação da sociedade.

A subordinação jurídica na relação de trabalho alcança apenas o labor do empregado, vinculando-se estritamente à executoriedade da atividade e normatividade organizacional. Vale destacar que o trabalho representa um fator de produção, gerenciado com finalidade própria (ALVARENGA, 2013). Os direitos humanos são o alicerce das relações de trabalho, seu imperativo moral. O reconhecimento do outro, como pessoa, é requisito de humanidade (MENEZES, 2008).

\section{Repercussão do assédio moral}

A caracterização do assédio moral corporativo assume contornos específicos, conforme o caso concreto. Todavia, no que concerne às consequências, é inequívoco que tais práticas criam mazelas institucionais:

- perda de motivação funcional e, em decorrência, de produtividade;

- isolamento social e alheamento crescentes;

- impotência diante dos desafios profissionais;

- entraves no desenvolvimento de carreiras;

- ruídos na comunicação, especialmente entre "setores-fornecedores" e "setores-clientes", gerando prejuízos diretos à organização;

- posturas invasivas à intimidade do indivíduo;

- banalização da prática de hostilização, o que contamina e estimula comportamentos afins, ensejando o silêncio coletivo conivente;

- ausências justificadas no trabalho e, em alguns casos, até afastamentos;

- perda gradativa da identidade do assediado, numa tentativa de adaptação e solução provisória do problema (fenômeno de identificador entre assediador e assediado);

- comportamentos defensivos;

- criação de zonas de tensão social no ambiente de trabalho, criando áreas de reclusão, ou em extremo, de conflitos improdutivos, evoluindo para violência explícita;

- culpabilização da vítima.

Os distúrbios causados à saúde do trabalhador são variados: crises de hipertensão, alterações da libido e do sono, síndrome do pânico, dores físicas, perda de apetite, dificuldades de concentração, cansaço, depressão, mudanças no metabolismo e problemas digestivos, entre outros. As patologias podem evoluir para graves doenças ocupacionais de natureza psicossomática ou psicossocial (ANTLOGA e COSTA, 2007; MERÍSIO, 
2012). Em razão dos prejuízos incorridos e potenciais, a criminalização revela-se como tendência no Brasil e realidade em grande parte dos países, especialmente, na Europa.

O assédio afeta a saúde física e mental do indivíduo, alcançando a coletividade na organização, já que influencia os relacionamentos interpessoais e o equilíbrio psicológico do indivíduo no ambiente laboral. O problema pode, inclusive, ocasionar patologias mais severas, culminando no extremo do suicídio, homicídio e outras formas não brandas de violência social.

O assédio moral repercute nas esferas biológica, biopsicológica e comportamental, o que implica destruir a qualidade de vida do indivíduo integralmente. $\mathrm{Na}$ verdade, tem consequências psicopatológicas, psicossomáticas e comportamentais (SOSSELA e NEVES, 2011). O quadro 1 relaciona sintomas físicos e psicológicos decorrentes do fenômeno.

Quadro 1

Repercussão do assédio moral

Possíveis efeitos produzidos pelo assédio moral

Sintomas físicos

Fadiga que evolui gradativamente

Distúrbio do sono

Hipertensão arterial

Taquicardia

Disfunções sexuais (impotência, ejaculação precoce e anorgasmia) / redução do nível de atividade sexual

Mudanças no ciclo menstrual

Cefaleias e enxaquecas

Transtornos alimentares e gastrointestinais

Dores musculares ou osteomusculares

Imunodeficiência

Sintomas psíquicos

Dificuldades de concentração

Lapsos de memória

Mudança de humor (ciclotimia)

Impaciência

Impotência diante dos desafios da vida, especialmente, oriundos do ambiente laboral. 


\section{Possíveis efeitos produzidos pelo assédio moral}

\section{Sintomas psíquicos (continuação)}

Redução da velocidade de raciocínio

Tristeza imotivada e prolongada (disforia), evoluindo ou não para um estado depressivo.

Sentimento de solidão

Angústia

Perda de referência de si mesmo.

Paranoia

Ansiedade

Labilidade emocional e afetiva (mudança brusca e geralmente, imotivada do humor ou ânimo)

\section{Sintomas comportamentais}

Irritabilidade (distimia)

Perda de identidade e interesse pelo trabalho

Deambulação

Negligência na prática laboral

Alheamento ou isolamento social

Agressividade

Consumo ou utilização exagerada de substâncias, lícitas ou ilícitas (a exemplo do álcool, cigarro, medicamentos etc.)

Tentativas de autoflagelo

Ímpetos de fuga da realidade

Pensamento introvertido

Onipotência diante do sentimento de fracasso

Hipervigilância

Ruptura de laços afetivos

Fonte: elaborado pela autora 
As práticas assediantes, comportamentos inequivocamente nocivos à vida social, atuam como agentes estressores cognitivos, porque ameaçam a saúde psíquica do trabalhador, tornando-o vulnerável às próprias emoções.

Os estressores cognitivos, no assédio moral, atingem o patrimônio psicossocial do indivíduo, afetando sua estabilidade profissional e emocional. Geralmente, a experiência assediante tem marcos bem definidos em relação àqueles correspondentes às vivências traumáticas. Em alguns casos, os agentes estressores revelamse como emocionais, podendo repercutir na vinculação afetiva entre assediador e assediado.

Naturalmente, a resposta à experiência de assédio moral depende das características da personalidade do assediado, grau de fragilidade emocional, duração das investidas assediantes e seu efeito encadeado (na rede de relacionamentos de ambos), nível de afetação da imagem, história de vida, condições atuais, predisposição à vitimização, meios de enfrentamento disponíveis (suporte psicológico especializado, existência de políticas organizacionais severas e códigos de ética), entre outros fatores. Os efeitos podem ser categorizados em fases:

- fase de reflexão sobre os fatos ou comportamentos assediantes -esse estágio é caracterizado pela busca por explicação ou negação imediata do problema (desativação emocional) (ZABALA, 2001);

- fase do revide impulsivo ou de conexão com o assediador- corresponde ao momento em que, sentindo-se agredido em sua dignidade, o assediado desenvolve o objetivo maior de responder à ofensa. Em muitos casos, esse objetivo passa a ocupar lugar central na vida da vítima. Nesse estágio, constata-se elevação dos níveis de ansiedade e tensão, repercutindo nas relações familiares. Não é também incomum o assediado consentir o assédio pela necessidade de manter o vínculo laboral ou por qualquer outra carência, criando fundamentos justificadores para a abordagem. Merísio (2012, p. 169) ratifica esse entendimento: "A vítima do assédio costuma reagir através dos seguintes comportamentos: negação do assédio; agressão contra o acusador e seus cúmplices (por ação ou omissão); internalização das acusações; submissão; ilusões; e somatização".

A reação de Poliana (caracterizada pela minimização do problema) é um exemplo típico de negação, revelando dissonância cognitiva.

Nas experiências de assédio moral, verifica-se que o ressentimento mobiliza a atenção da vítima, obstruindo seu poder de iniciativa, impedindo-a de progredir socialmente, estabelecendo outras prioridades (SCHLINDWEIN, 2013). Esse desvio de atenção pode culminar em um processo obsessivo, caracterizado pela referência constante, nos diálogos correntes, aos traumáticos episódios vivenciados e pensamentos continuados voltados para o problema (ora revivendo os fatos, ora fantasiando situações de revide). Esse comportamento pode, inclusive, ensejar exclusão social.

- fase do exaurimento físico e mental - onde a vítima tem suas reservas emocionais comprometidas e a ansiedade silenciada pelo sofrimento íntimo, afetando sua concentração e objetividade diante do problema.

Rojo e Cervera (2005) definem como fases do assédio moral o surgimento do conflito, redundando em ataques diretos e indiretos, e a instauração do assédio (concretude das investidas e incidentes críticos). Por sua vez, alguns autores incluem fases intermediárias como a estigmatização (ridicularização da vítima) e intervenção da administração da empresa.

Ocorre que nem sempre o assédio é visível aos olhos de terceiros. A intervenção da cúpula diretiva não é algo comum, especialmente, porque intervir implica assumir responsabilidade. A pessoa jurídica responde pelas ações de seus prepostos. Deve ser acrescentada ainda a possibilidade da administração assumir uma postura de indiferença social.

Em algumas realidades organizacionais, as "ilhas" não são grupos e sim "pessoas". 
O assédio moral pode levar à exaustão emocional (esgotamento físico e mental), à despersonalização e à redução gradativa da autoestima e satisfação pessoal no trabalho.

As organizações são espaços de aprendizado, interação, amadurecimento e acolhimento, o que justifica a sensação de perda, desamparo e de despertencimento do assediado àquele grupo social (SCHLINDWEIN, 2013).

A despersonalização da vítima se caracteriza pelo alheamento, indiferença, distância interpessoal e impessoalidade no trato com seus pares (parceiros, colegas, clientes, fornecedores), o que pode ser interpretado como cinismo, complexo de superioridade ou, mesmo, ironia, influenciando sua socialização. Isso significa que a exclusão social do assediado nem sempre é direta, vinculando-se às suas reações (efeito encadeado).

O assediado pode perder a referência de si mesmo (autovisão de sua capacidade e potencial), contaminandose pelas impressões perniciosas do assediador (ARGIMON, GAUER e OLIVEIRA, 2009).

Em síntese, o assédio moral afeta negativamente a produtividade, o senso de realização profissional, o desempenho, a criatividade e inovação do assediado, com prejuízo de sua saúde mental e da organização para a qual trabalha. Rotatividade de pessoal, absenteísmo, frequência de conflitos improdutivos e comprometimento da qualidade de serviços são alguns dos efeitos.

Alguns ambientes corporativos são facilitadores de iniciativas assediantes quando estimulam a competição e o individualismo, em lugar da cooperação, comprometimento, sinergia e trabalho em equipe. As reações são diversas, como variado é o conjunto de componentes que dosifica esse impacto.

O estudo de práticas persecutórias e invasivas estimula a investigação empírica acerca da satisfação do indivíduo no trabalho, que não se restringe exclusivamente à renda, contrapondo-se à ideia de que a sociedade do trabalho é meramente salarial.

A "medicalização" do conceito desconsidera a importância de aspectos relacionados à vida social e aos riscos laborais de natureza social (LUQUE, 2006).

Lembre-se que assédio moral é considerado uma patologia sociolaboral. O impacto decorrente do comportamento assediantes enseja consequências que alcançam desde o indivíduo ao grupo que o integra. Essa repercussão perpassa a dimensão psicológica, alcançando a patrimonial em relação ao agente que empreendeu o assédio moral.

Olivares (2005) destaca as perspectivas pelas quais o trato degradante deve ser analisado: a pessoal e aquela meramente profissional. Isso implica afirmar que o fenômeno pode ser investigado segundo os reflexos na vida do indivíduo em sua integralidade.

Para as organizações, os efeitos sobre sua imagem são nefastos, reproduzindo publicidade negativa, além de perdas materiais significativas. O quantum de ressarcimento por dano moral é proporcional à lesividade do ato e ao grau de reprovação social da conduta.

Em síntese, a exposição ao ostracismo patrocinado pelo assédio moral ameaça necessidades sociais fundamentais aos povos.

\section{Identificação com o agressor como forma de reação}

A submissão à agressão psicológica denuncia uma característica frequente e, talvez, distintiva do assediado, a baixa autoestima, que é o ingrediente essencial à estabilidade da conduta e ao assentimento do assédio (determinante de sua continuidade) (ARGIMON, GAUER e OLIVEIRA, 2009; ZABALA, 2001; 2008b). 
Não é incomum a identificação do assediado com o assediador como iniciativa de arranjo, alternativo em relação ao enfrentamento da situação desconfortável.

[...] em alguns casos a instalação na situação costuma ocorrer mediante o desenvolvimento de orientações de condutas masoquistas, com as quais a vítima do assédio psicológico tende a evadir-se de sua insuportável sensação de solidão e impotência. Seus sentimentos de insignificância, unidos a outros possíveis de inadequação, fazem com que busque no assediador alguém a quem ligar-se para, desse modo, renunciar a sua egoidade ou individualidade. (ZABALA, 2001, p. 230)

A renúncia à própria individualidade consolida a vítima como polo hipossuficiente dessa relação, sensível aos ditames do assediado. Igualmente, estabelece um processo simbiótico. A vítima, fragilizada psicologicamente, ingressa numa espiral de indefensibilidade. A falta de reação inicia um processo de autofagia da vida profissional.

Hirigoyen (2013a, p.15) pontua que:

Uma persona que há padecido uma agresión psíquica como ela coso moral es realmente uma víctima, puesto que su psiquismo se há visto alterado de um modo màs o menos duradouro. Por mucho que su maneira de reaccionar a la agresón moral pueda contribuir a estabelecer una relación com el agressor que se nutre de sí misma y a dar impresión de ser 'simétrico', no hay que olvidar que esta persona padece uma situación de la que no es responsable.

A admissão do juízo de valor do agressor representa um consentimento à prática. Com efeito, a identificação momentânea pode encerrar diferentes mensagens: de dúvida, insegurança, complexo de inferioridade, solidão, sentimento de insignificância e inadequação, medo ou mesmo confusão. Esse encaixe produzido pela identificação, na psicologia clínica, é denominado de colusão (ZABALA, 2001).

O elemento essencial do processo descrito é a submissão por parte da vítima. A colusão ou simbiose, já identificada em diferentes modalidades de relações (entre amigos, casais, pais e filhos), traduz uma fusão de identidades com ofuscamento daquela do assediado (SILVA, 2003).

O silenciamento observado nessas atuações estabelece uma conivência prolongada induzida, estendendo o ciclo de vida da prática assediante. A conivência ativa e passiva institucionalizam comportamentos, mascarando a nocividade da relação (viés de enquadramento).

Nessa análise, deve ser considerada ainda a possível presença de características facilitadoras no perfil da vítima, o que a torna receptiva ao assédio: tendência em elaborar uma correlação positiva entre nível intelectual/moral e hierárquico, promovendo o encastelamento social de determinados pares; carência afetiva e dependência; fragilidades de conhecimento (especialmente, na função que desempenha); subestimação defensiva; imaturidade profissional (inexperiência), o que leva à superlativização da figura do assediador; inclinação à negação de realidades desconfortáveis e à subserviência; estado de infelicidade; além da aversão ao risco ou fracasso, entre outras.

Sanchez (2003) classifica o perfil das vítimas de assédio moral em quatro categorias: 1-pessoas brilhantes e carismáticas, naturalmente, competitivas; 2 -aqueles que padecem de alguma mazela física (considerada pela sociedade como "defeito"); 3-pessoas com tendência à depressão e carentes afetiva ou emocionalmente; portanto, psiquicamente fragilizadas; 4-profissionais preparados, eficazes e produtivos, atributos que os colocam em evidência.

O autor destaca ser importante considerar o perfil da vítima como variável facilitadora ou mesmo, o próprio gatilho do comportamento assediante (análise desprovida de qualquer juízo moral). 
Ao que parece, os motivos e variáveis são diversos e têm sido objeto de estudos, especialmente, na área de psicologia.

Algumas características do agressor também favorecem o empreendimento da prática no âmbito corporativo: dificuldade em gerenciar competências, emoções e o processo de aprendizagem nas organizações; anseio por controle; vaidade; ambição desmedida; inclinação à dominação; dificuldade em reconhecer a importância e o papel da diversidade para o amadurecimento social; narcisismo exagerado (pensamento autorreferencial); comportamento defensivo, ainda que se apresente na forma de reação; necessidade de autoafirmação profissional e reconhecimento pelos pares, entre outras.

A falta de solidariedade coletiva constitui elemento essencial e, talvez, até a amálgama desse alinhamento de perfis. De fato, o assédio moral é geralmente silencioso e acompanhado da introjeção de culpa por parte da vítima. A experiência também é marcada pela renúncia dos pares (colegas) ao testemunho, à denúncia, ao acolhimento fraterno à pessoa assediada, mantendo-se inertes e indiferentes ao fato observado. Em alguns casos, esse alheamento dispara a elaboração mental de justificativas para explicar o comportamento do agressor.

A relação assediado-assediador apresenta graus distintos de toxidez, o que influencia a velocidade de resposta (ROSS, 2013). Inexiste uma forma padrão de enfrentamento do problema. Alguns mecanismos de defesa são sutis, enquanto outros são mais assertivos e eficazes.

Zabala (2008b) destaca que a superação do assédio reclama a eliminação de características facilitadoras, geralmente, presentes no perfil da vítima: submissão, dependência, insegurança e baixa autoestima. Todavia, o mascaramento social da prática constitui óbice ao esboço de qualquer reação, porque o assediador comunica a falsa impressão de correção.

Zabala (2001) descreve as possíveis personalidades do assediador, visando compreender o fenômeno e identificar a raiz patológica do comportamento do assediador (fatores de ordem pessoal). Dentre as personalidades referenciadas, destacam-se aquela paranoide, psicopática e a narcisista.

O indivíduo com personalidade paranoide estabelece, em torno de sua atuação, uma redoma de segurança. Apresenta nível elevado de desconfiança e ciúme, esboçando suspeitas invasivas, injustificáveis e infundadas, cultivando ideação persecutória (CROMBERG, 2001; GABBARD, 2007; RIGOLIN e CAMARGO, 2004; ZABALA, 2001). Esse padrão de assediador mantém-se em prontidão de atenção e defesa. Com esse intento, lança mão de sistemas de violação à privacidade das comunicações de seus subordinados, e, assim, o nível de desconfiança pode alcançar níveis patológicos. O assediador paranoide usualmente:

- desqualifica os motivos do outro, os quais, em sua opinião, são sempre carregados de maledicência;

- vitimiza-se, adotando como justificativa um pseudo status de exploração no ambiente laboral;

- atribui significados negativos a ocorrências em contextos favoráveis ou salutares;

- desenvolvem rancores duradouros;

- reagem intensamente a conflitos, lançando mão de insultos implacáveis, sarcasmo, queixas, hostilidade;

- criam trincheiras invisíveis no ambiente de trabalho (CROMBERG, 2001).

Os paranoides podem apresentar-se estáveis, “[...] especialmente se seu trabalho não exigir muita cooperação com outras pessoas; mas podem apresentar dificuldade com figuras de autoridade e em relacionamentos íntimos, que evitam pelo medo de dominação e vulnerabilidade" (CROMBERG, 2001, p. 25-26).

A personalidade psicopática apresenta as seguintes características comportamentais: irresponsabilidade com o outro; uso do encanto (superficial) para envolver; manutenção de segredos na atuação social (máscaras); 
autoritarismo; assertividade; autoconfiança; inteligência e loquacidade notáveis; impulsividade; autovalorização exacerbada; arrogância; dificuldade em demonstrar afeto aos seus pares; insensibilidade ou indiferença aos resultados de seus atos; ausência de empatia (no sentido de colocar-se no lugar do outro); uso indiscriminado de recursos de manipulação; criação de um mundo a parte, onde suas ideias são válidas (ZABALA, 2001, 2008a).

Daynes e Fellowes (2012) ratificam as seguintes características do psicopata (posicionado no ambiente laboral): autoritarismo arrogante, autoconfiança delirante e despreocupação em relação ao fracasso.

Zabala (2008a, p. 19) destaca que esses personagens corporativos "Son astutos, carismáticos, atractivos y dotados de habilidades sociales. Suelen producir uma inmejorale primera impresión cuando se les conoce".

A pessoa dotada de personalidade narcisista apresenta uma necessidade incomum de admiração e devoção, o que o remete ao seu anseio de ocupar status de relevo em relação aos demais, padecendo, em muitos casos, de empatia (no sentido de colocar-se no lugar do outro). De fato, sentem-se diferenciados. Com efeito,

Indivíduos narcisistas são caracterizados por fantasias irreais de sucesso e senso de serem únicos, hipersensibilidade à avaliação de outros, sentimento de autoridade e esperam tratamento especial. Frequentemente, apresentam sentimento de superioridade, exagero de suas capacidades e talentos, necessidade de atenção, arrogância e comportamentos autorreferentes (DORFMAN, GUS, CATALDO NETO et al., 2003, p. 609).

O narcisista centraliza as atividades em torno de si mesmo, criando expectativas de feedback social, geralmente, frustradas.

Muitas iniciativas de assédio advêm de um desejo do agressor em adestrar as pessoas a seu redor, para que correspondam às suas expectativas. Os instrumentos usuais são a catequese e a coerção (SIMM, 2008).

A ecologia organizativa contribui igualmente para a incidência do comportamento assediante. São exemplos de fatores relacionados à ecologia organizacional: o estilo da gestão de processos e pessoas e os critérios de delegação e avaliação de desempenho, o que pode acirrar a concorrência interna, tornando-a, em alguns casos, predatória.

\section{Identidades organizacionais e 0 assédio moral de linha}

As relações trabalhistas são essencialmente políticas. As organizações são complexos sociais que compreendem diferentes grupos cujos membros se unem a partir de crenças, valores, necessidades, interesses profissionais e pessoais comuns ou, mesmo, da afetividade partilhada (instrumentos de coesão e integração). Essas categorias sociais apresentam sintonia e atributos próprios, cristalizando identidades (localizadas) que, juntas, partilham o que se denomina de identidade organizacional (OLIVEIRA, 2008).

Parte dessa identidade dita coletiva é individual, refletindo predominantemente as referências das pessoas que integram aquela realidade social. Essas identidades localizadas determinam condutas e estabelecem relações de poder paralelos àqueles institucionalizados. Acredita-se que dessas interfaces nasce o assédio moral horizontal, como resultado da repercussão das ligações identitárias e do confronto das respectivas forças sociais.

A identidade social é uma abstração que compreende atributos próprios do indivíduo em seu autoconceito. A matriz autorreferente dessa identidade é definidora de comportamentos, determinando o modus como o indivíduo percebe o outro, suas ideias e a própria organização.

A formação desses grupos e redes sociais se dá por meio da identificação, e de modo natural, como consequência de necessidades como segurança, respaldo político, inclusão social, afiliação (vinculação) e 
autopromoção entre outras. Os limites, a dimensão simbólica dos espaços sociais que circunscrevem esses grupos têm natureza diversa (ideológica, afetiva, ética, emocional, valorativa, política, técnica, motivacional e psicológica). Atuam protegendo aquela identidade social, criando uma barreira ao ingresso de indivíduos que não compartilhem daquela matriz de comportamento autodefinidora.

Essas identidades determinam atitudes no trabalho, desempenho, conflitos (produtivos ou não), dependência, motivações, nível de satisfação e comprometimento, além de explicarem políticas e iniciativas de socialização. Os grupos identitários não são estáticos porque as organizações não são isoladas do mundo e de suas interferências. O estudo dessa identificação importa à caracterização do assédio de linha, que se define por condutas que comunicam mensagens vexatórias ou coercitivas (explicita ou implicitamente) dirigidas ao seu alvo. Essas mensagens são revestidas, muitas vezes, de uma agressividade subliminar; invisível, portanto, a olhos desatentos.

O desenho da identificação social (por afinidade ou imitação) pode determinar comportamentos assediantes. Essa identificação independe de interação. O silêncio, o alheamento e a conivência passiva também são instrumentos ratificadores de condutas. $\mathrm{O}$ assédio moral advém do abuso de mecanismos de controle e repressão, que não se origina exclusivamente das lideranças formais. Deve ser ressaltado que o poder justifica-se essencialmente pela necessidade de uma disciplina mínima, visando à conciliação da vontade política dos agentes e não para fomentar práticas coercitivas e cerceantes da liberdade do individuo (OLIVEIRA, 2008).

A compreensão das origens do assédio moral de linha passa por uma reflexão sobre as práticas sociais, relações de poder e influência. $\mathrm{O}$ poder coercitivo e intolerante é assediante por natureza. A principal dificuldade em identificar esse tipo de assédio moral é a existência das máscaras sociais, previamente determinada pelas formalidades sociais próprias dos ambientes profissionais. Esses figurinos corporativos decorrem de regras consagradas, socialmente aceitas e cristalizadas.

O poder corresponde a uma relação social que determina, em doses toleráveis, relacionamentos assimétricos. Cada agente, indistintamente, possui alguma parcela de poder, o que sugere que todas as relações sociais são, em essência, assimétricas. Seu exercício independe de posição hierárquica. Significa que mesmo aquele que ocupa posição subalterna pode exercer um contrapoder (HILAL, 2003; OLIVEIRA, 2008).

O assédio moral de baixo para cima decorre do uso do contrapoder. Atente-se para o fenômeno social da influência exercida por autoridades políticas não legitimadas, que também podem dar azo a práticas assediadoras na organização. A influência manifesta-se pela expressão das competências de persuasão e ascendência sobre outras consciências, no sentido de estimular comportamentos espontâneos, consentidos. Baseia-se em símbolos, prescindindo de controles formais. Trata-se de um subsistema ideológico presente na identidade social das organizações (PAZ e NEIVA, 2014; SROUR, 2012).

O quadro 2 diferencia poder e influência. "Em tese, o terreno da influência não é o do irracional e da fé ações emocionais, tradicionais, axiológicas -, mas o terreno preferencial da razão, dos raciocínios elaborados e da persuasão fundamentada" (SROUR, 2012, p. 97-98). 
Quadro 2

Diferenças entre poder e influência

\begin{tabular}{|c|c|}
\hline Poder & Influência \\
\hline Autoridade legitimada. & Autoridade (moral, científica, técnica). \\
\hline Mando formalizado. & $\begin{array}{l}\text { Caráter simbólico, não político (no sentido } \\
\text { institucional). }\end{array}$ \\
\hline $\begin{array}{l}\text { Adesão baseada em justificativas formais, a } \\
\text { exemplo da submissão decorrente de } \\
\text { exigências contratuais ou regimentais. }\end{array}$ & $\begin{array}{l}\text { Adesão baseada no convencimento, expressão } \\
\text { da vontade dos pares. }\end{array}$ \\
\hline Motivação legal, institucional. & $\begin{array}{l}\text { Motivos: ideológicos, técnicos, estéticos, } \\
\text { científicos. }\end{array}$ \\
\hline $\begin{array}{l}\text { Resulta em comportamentos preditos e } \\
\text { esperados. }\end{array}$ & Resulta em ações consentidas e convicções. \\
\hline $\begin{array}{l}\text { Meios de difusão: sistema de regras } \\
\text { (regimentos, regulamentos), leis, portarias e } \\
\text { contratos, entre outros. }\end{array}$ & $\begin{array}{l}\text { Meios de difusão: comportamentos } \\
\text { inspiradores, diálogos informais e mídias, a } \\
\text { exemplo das redes sociais e iniciativas de } \\
\text { instrução, entre outros. }\end{array}$ \\
\hline Emprego de meios físicos. & Aporte de meios cognitivos. \\
\hline Alto grau de formalidade. & Inexistência de padrões formais. \\
\hline Forte regulação. & Flexibilidade. \\
\hline Sanções contratuais. & $\begin{array}{l}\text { Sanções simbólicas, a exemplo da simples } \\
\text { expressão de desagrado ou invisível exclusão } \\
\text { social. }\end{array}$ \\
\hline Presença de equipes diretivas. & Apresentam lideranças informais, genuínas. \\
\hline
\end{tabular}

Fonte: elaborado pela autora.

Embora a influência se utilize dos mecanismos de convencimento visando à adesão voluntária do indivíduo àquele grupo social, não se pode afirmar que a mesma seja vazia de emoção e valoração, o que pode comprometer a racionalidade na formação de juízos coletivos e decisões colegiadas.

A alienação ideológica, os discursos falaciosos, a burla e o logro estão presentes nas relações de poder e influência, ensejando formas espúrias de agressões simbólicas.

O abuso, independentemente de sua origem, se decorrente das relações de poder ou influência, surge quando o confronto das forças sociais ganha musculatura tal que afeta a dignidade dos pares.

Um ponto crucial a ser considerado é a maneira como se verifica a apropriação do significado da influência e o influxo de ideias; dito de outra forma: os meios e objetos de difusão, visto que ocorrem muitas vezes de modo silencioso, propagando práticas assediantes, ordens de vulneração e vícios corporativos. 
O assédio moral corporativo, em geral, corresponde a uma espécie de invasão ao espaço de decisão e expressão do indivíduo, aquele que configura sua identidade na organização. Trata-se de um aviltamento de liberdades. Esse 'espaço de decisão e expressão' limita o que se define por dignidade humana. É também nele que o indivíduo é fiel a sua verdadeira identidade, sem os óbices impostos pelos regramentos sociais. Esse espaço é preenchido pela sua intimidade, cuja tutela é prevista no ordenamento jurídico (direito de personalidade). É o espaço do "ser", onde o sujeito é livre e autônomo; liberdade essa, no entanto, restringida pelo senso de solidariedade social.

A liberdade geral de ação implica um direito prima facie e uma permissão prima facie. Cada um tem o direito a que o Estado não impeça as suas ações e/ou omissões, bem como uma permissão para fazer ou não fazer o que quiser. Qualquer restrição a esta liberdade deve estar assentada em lei e, para isto, deve apresentar razões relevantes e constitucionalmente válidas, assentadas, em geral, no direito de terceiros ou no interesse coletivo. (MENEZES, 2008, p. 124)

A identidade de uma pessoa não se restringe a signos ou sinais diferenciadores (honra, intimidade, vida privada e autoria intelectual). Compreende também qualidades, pontos de vista, crenças, atributos peculiares, opções ou escolhas, pensamentos, cultura, posicionamentos profissionais, políticos e religiosos, elementos que em conjunto configuram suas posturas diante do mundo. Raciocínio análogo se estende à identidade dos grupos sociais.

A composição da identidade do indivíduo não é estática, cambiando conforme a evolução da própria célula social a qual pertence. Vale lembrar que, parte dos elementos ideológicos são produções culturais, refletindo um modo de pensar institucionalizado pela tradição. O homem é um produto cultural inacabado dotado de inteligência e livre arbítrio.

Embora as organizações sejam ambientes democráticos de convivência política, os limites individuais e institucionais segregam papéis, criando zonas de atuação e significação. O poder de direção (mando) do empregador apresenta limites. Restrições estas impostas pelos direitos fundamentais. Exorbitar no exercício desse poder constitui prática abusiva. Essas divisórias sociais invisíveis (mas sensíveis), quando invadidas, configuram o assédio moral.

\section{Princípio da dignidade humana}

Embora de limites imprecisos, o instinto humano reconhece quando sua dignidade é lesionada. Por essa razão, o seu significado tem, além de um componente inato, elementos culturais e históricos (CAICEDO, 2012).

A sociedade é uma fonte natural de valores, internalizados pelo indivíduo, com notória repercussão em sua conduta.

Apesar da obviedade aparente, García (p. 20, 2001) enfatiza que "[...] es muy difícil determinar com carácter general y omnicomprensivo cuando se lesiona la dignidad humana y que ante lós casos difíciles la discusión y la argumentación precisam ser contextualizadas trasladadas a lós hechos concretos".

O conceito de dignidade não entrega uma fórmula vazia, muito menos politicamente neutra. Não obstante exista uma essência reconhecida universalmente, a dignidade humana é naturalmente carregada de valoração moral, o que confere plasticidade própria e um desenho contextual. É esse caráter valorativo, e não descritivo, que compromete o elenco de parâmetros intersubjetivos de sua aplicação na prática jurídica, ampliando naturalmente seu escopo e aquiescendo discussões sobre os limites desse enquadramento conceitual. 
A abordagem principiológica comunica valores humanísticos ao ordenamento (segurança, liberdade, autonomia e igualdade), necessários à preservação da pessoa humana e de uma harmônica coexistência social (CAICEDO, 2012; GARCÍA, 2001).

O princípio da dignidade, cuja natureza é essencialmente ético-jurídica, compreende o direito irrenunciável de exercício da autonomia e a ponderação dos limites dos espaços de expressão das vontades, definindo um contraponto à solidariedade social. $\mathrm{O}$ sentido desse conceito alcança a coletividade quando o indivíduo reconhece o outro como seu semelhante, estabelecendo um comportamento ético e respeitoso e, em alguns casos, um elo afetivo. Significa que o conceito de dignidade aplica-se nos níveis individual e coletivo.

Na visão kantiana, a razão não se desata dos paradigmas valorativos e da experiência histórica do homem, igualmente de seus apetites e atributos, a exemplo da afetividade, indulgência e solidariedade.

Em um Estado democrático de direito vive-se em regime de coliberdade, o que pressupõe dignidade social e respeito aos espaços individuais e àqueles compartilhados.

Sendo assim, a liberdade jamais poderia ser considerada em termos absolutos, pois naturalmente estaria condicionada. Esses condicionantes que impõem resistência à plena realização do ato livre apresentam-se nas mais variadas formas, seja pelas peculiaridades intersubjetivas do ser, seja a envoltura psicossomática, seja a própria presença e percepção dos outros e das coisas (objetos) que nos rodeia. (DONOSO, p. 35, 2013)

A vontade individual é prisioneira da necessidade de viver coletivamente, o que torna a liberdade um mito. Destarte, a coexistência constitui obstáculo ao exercício pleno da liberdade.

O senso de pertencimento social e à condição inata de sujeitos livres são fontes naturais de paradigmas de moralidade, impondo à espontaneidade um caráter relativo. Essa constatação ratifica o entendimento de que a independência do arbítrio do homem se subordina aos limites do espaço da existência do outro (BUSSINGUER,2008; DINIZ, 2008; DONOSO, 2013).

Em decorrência de sua natureza, o senso de dignidade humana impõe-se à conduta das pessoas em relação aos seus pares na sociedade, como uma espécie de "medida" ou "norma-limite", dosador ou filtro de comportamentos, ensejando compromissos juridicamente vinculantes.

Para Moraes (2011, p. 48) dignidade é:

[...] um valor espiritual e moral inerente à pessoa, que se manifesta singularmente na autodeterminação consciente e responsável da própria vida e que traz consigo um mínimo invulnerável que todo estatuto jurídico deve assegurar, de modo que, somente excepcionalmente, possam ser feitas limitações ao exercício dos direitos fundamentais, mas sempre sem menosprezar a necessária estima que merecem todas as pessoas enquanto seres humanos.

O conceito estabelece limites ao espaço preenchido pela integridade moral do homem, nucleados por atributos primários e secundários. 


\section{Quadro 3}

Atributos definidores da dignidade humana

\begin{tabular}{|c|c|c|}
\hline Atributos primários & Atributos secundários & $\begin{array}{l}\text { Comportamentos } \\
\text { (condutas aviltantes) }\end{array}$ \\
\hline $\begin{array}{l}\text { Liberdade de "ser" (ente } \\
\text { psicológico), segundo sua natureza, } \\
\text { escolhas, distintas ou não do } \\
\text { padrão cultural estabelecido, } \\
\text { predominante e socialmente } \\
\text { aceito. }\end{array}$ & $\begin{array}{l}\text { Identidade } \\
\text { (condições de vida íntima) }\end{array}$ & $\begin{array}{l}\text { Invasão de privacidade - insultos } \\
\text { - críticas infrutíferas - exposição } \\
\text { pública não autorizada- } \\
\text { isolamento social - agressividade } \\
\text { - tratamentos degradantes em } \\
\text { todos os níveis. }\end{array}$ \\
\hline $\begin{array}{l}\text { Liberdade de "estar" socialmente, } \\
\text { respeitando os limites de exercício } \\
\text { desse direito. } \\
\text { Liberdade de desenvolvimento } \\
\text { psicológico e intelectual. }\end{array}$ & $\begin{array}{l}\text { Existência social } \\
\text { (condições mínimas para uma } \\
\text { convivência saudável em } \\
\text { sociedade) }\end{array}$ & $\begin{array}{l}\text { Agressões verbais -- exclusão } \\
\text { social - discriminação - } \\
\text { constrangimento e humilhação } \\
\text { em razão de sua condição ou } \\
\text { estado. }\end{array}$ \\
\hline $\begin{array}{l}\text { Liberdade decisória (de ação, } \\
\text { direção, comando sobre a própria } \\
\text { vida). } \\
\text { Aptidão para agir ou omitir-se } \\
\text { conforme seus próprios critérios } \\
\text { definidores. } \\
\text { Capacidade de elaborar seu projeto } \\
\text { de vida, à luz de suas escolhas. }\end{array}$ & $\begin{array}{l}\text { Autonomia } \\
\text { (livre escolha e ação) }\end{array}$ & $\begin{array}{l}\text { Práticas cerceadoras da liberdade } \\
\text { de escolha, o que se traduz em } \\
\text { posturas invasivas. }\end{array}$ \\
\hline $\begin{array}{l}\text { Liberdade de expressão e de } \\
\text { informação. }\end{array}$ & Expressão & Censura de modo geral. \\
\hline
\end{tabular}

Fonte: elaborado pela autora.

Os atributos primários (genéricos e agregadores) decompõem-se naqueles secundários (pontuais, específicos), conferindo-lhe a amplitude necessária ao enquadramento nas situações jurídicas.

As liberdades supracitadas, naturalmente, apresentam limitações de exercício, em face da coexistência do homem em sociedade e dos atributos da personalidade, bem como da incidência de normas de controle, disciplina moral e regramentos sociais oriunda dos costumes. Todavia, sua expressão dentro desses limites dosadores é plena, irrestrita e irrenunciável. Nessa direção, Einarsen (2005) define o assédio moral como privação da autoestima, do senso de dignidade e pertencimento social, de amor e carinho. Segundo os autores, o assédio moral cerceia a liberdade da vítima, controlando suas interações com os outros.

O princípio jurídico da dignidade humana oferece substrato à tutela legal ao desenvolvimento da personalidade e a todas as formas de expressão segundo a mundividência do próprio indivíduo, que comporta aspectos morais, intelectuais e físicos. "A dignidade da pessoa humana funciona como cláusula geral do direito de personalidade" (MENEZES, 2008, p. 124).

A dignidade como princípio vetor da atividade jurídica tem função protetiva no ordenamento legal, alcançando todas as relações. Nesse desiderato, 
[...] o papel do Direito do Trabalho é assegurar que a lógica da dignidade impere, e não a lógica do preço; garantir que o trabalhador seja visto como homem, e não como uma mera engrenagem da produção; garantir que a remuneração seja fixada conforme as necessidades mínimas de sustento, e não de modo a servir somente à diminuição dos custos produtivos. (BUSSINGUER,2008, p. 127)

Sem negar sua função emancipatória “[...] o papel do Direito não é apenas regular o comportamento humano, mas regulá-lo levando em consideração que o ser humano é seu ponto de partida (núcleo central em termos de conteúdo), seu criador formal e seu destinatário" (DONOSO, 2013, p. 38).

As diretivas do princípio, na verdade, se irradiam a todos os ramos do direito, impondo, paradoxalmente, limites às liberdades tuteladas, resguardando a harmonia social.

\section{Procedimentos Metodológicos}

Foram definidas como campo as situações jurídicas analisadas, além do conteúdo apresentado pelos autores revisados. Entende-se que as leituras impressas pelos autores são ricas em significado, viabilizando a exploração das diferentes perspectivas de análise do problema. Acredita-se que esses pontos de vista são profusores potenciais de fundamento, opinião e referência à prática corporativa. Assim, essa pesquisa enquadra-se como qualitativa de cunho descritivo-exploratório, tendo em vista a natureza dos dados e objetivos propostos, com abordagem propositiva no que tange à análise das consequências no âmbito gerencial.

Os estudos de natureza qualitativa, em geral, baseiam-se na perspectiva dos sujeitos da pesquisa, o que implica a captação de suas interpretações, impressões, sentimentos, pontos de vistas, leituras, percepções, experiências observadas ou vivenciadas.

A categorização da pesquisa como exploratório-descritiva justifica-se pelas atividades previstas na consecução dos objetivos enunciados, os quais compreenderam o apanhamento de abordagens analisadas e o reporte das mesmas.

Os objetivos exigiram necessariamente a análise sistemática das leituras apresentadas pelos autores revisados, com os objetivos principais de identificar e compor o eixo estruturante do trabalho (grade de revisão e construto).

As seções e subseções deste artigo serão discutidas sob a orientação dos objetivos enunciados e análise contextualizada da produção desses autores.

Deve ser destacado que, a pesquisa nos moldes apresentados,

[...] não se reduz a uma apresentação das ideias de diferentes autores acerca do tema estudado. Do contrário, exige do pesquisador a produção de argumentações sobre o tema, oriundas de interpretação própria, resultado de um estudo aprofundado sobre o assunto. Concordar, discordar, discutir, problematizar à luz das ideias dos autores lidos são os procedimentos dessa modalidade de pesquisa. (TOZONI-REIS, 2009, p.36)

A escolha metodológica adequa-se à natureza da delimitação temática sugerida e às características dos dados mapeados:

Pesquisas na abordagem qualitativa se caracterizam, principalmente, por estudar subjetividades, crenças, valores, representações da realidade, opiniões, enfim, fenômenos 
intrinsecamente complexos. Comportam observações, intensivas e prolongadas, em ambiente natural, cujos registros devem ser precisos e detalhados para que as informações colhidas possam ser analisadas detalhadamente, embora esta análise não possa ser generalizada. (FAGUNDES, 2009, p. 21)

De fato, as pesquisas de natureza qualitativa, de modo geral, compreendem uma grande diversidade de materiais empíricos, o que alcança desde sentimentos a experiências pessoais, narrativas de vida, relatos de introspecções, produções culturais diversas; enfim, materiais que comunicam os significados atribuídos pelo indivíduo à vida em sociedade.

Dessa exposição metodológica, depreende-se que o enquadramento metodológico descrito harmoniza-se com a abordagem efetivamente desenvolvida, visto que "[...] interessa muito mais compreender e interpretar seus conteúdos que descrevê-los." (TOZONI-REIS, 2009, p.15)

A revisão de literatura teve como start o levantamento realizado nas bases de dados Directory of Open Access Journals (DOAJ) e SciELO Brazil (Scientific Electronic Library Online), orientado metodologicamente por uma abordagem indutiva, buscando-se fundamentos para a elaboração da argumentação apresentada, além de analisar os recortes e contribuições.

O estudo foi conduzido como segue: 1- delineamento da pesquisa (elaboração dos elementos metodológicos estruturantes do trabalho); 2-coleta e organização de dados, análise e interpretação; 3- análise de 30 casos concretos, presumidamente de assédio moral, conduzida paralelamente à revisão de literatura e aporte de experiências internacionais (Direito comparado); 4-identificação das características e consequências da prática assediante, bem como dos argumentos apresentados; 5 - confronto entre a caracterização delineada, a partir da revisão de literatura, e aquela obtida com base no levantamento empírico.

\section{Resultados e Análises}

É indiscutível que o assédio moral ultrapassa os limites do poder de mando do empregador, implicando a existência de condições imperfeitas de desenvolvimento do trabalhador, no que se refere às competências, destrezas e habilidades, especialmente, aquelas de natureza emocional e social.

A configuração do assédio moral para fins jurídicos exige inequívoca comprovação do fato, do dano gerado e seu grau de lesividade (magnitude da repercussão psicológica), nexo causal fato-dano, além de exaustiva contextualização. Essa caracterização se insculpe considerando um complexo de variáveis (psicológicas, históricas, socioeconômicas, estratégicas, organizacionais etc.) que se imbricam na definição da prática.

Dano psíquico define-se como distúrbio, disfunção ou transtorno que afeta as dimensões afetivas, intelectual ou mesmo volitiva do indivíduo, restringindo sua capacidade de autodeterminação e reação aos estímulos do mundo (no recorte em tela, mundo do trabalho). O reconhecimento desse dano, em alguns casos, é tão complexo que exige avaliação médica, requerendo, igualmente, um diagnóstico etiológico para que o nexo causal seja identificado.

A avaliação dos casos reclama prudência e análise circunstanciada do fenômeno por parte do magistrado, igualmente dos demais operadores do direito e atores envolvidos. Uma descrição desatada do contexto pode induzir qualquer intérprete à configuração do assédio moral e, na verdade, ser tão somente uma ficção da suposta vítima, que apenas visualiza o fato de uma perspectiva contaminada por sua autovisão. Significa afirmar que o indivíduo pode imprimir sentido a um fato (série de atos) a partir da imagem que tem sobre si mesmo, igualmente, de seus sentimentos e carências.

Um dos óbices à identificação do assédio moral é que as abordagens do assediador em relação ao assediado são interpretadas como brincadeiras inocentes, mascarando seu real propósito. A análise dos casos revela o 
grau de dificuldade para compor a prova. Por essa razão, a jurisprudência nacional é rica em posicionamentos contrários àquele pretendido pelo assediado, negando a indenização pretendida.

ASSÉDIO MORAL NO TRABALHO. DEVER DE REPARAR. Assédio moral, "bullying" ou terror psicológico, no âmbito do contrato de emprego consiste na conduta abusiva do empregador ao exercer o seu poder diretivo ou disciplinar, atentando contra a dignidade ou integridade física ou psíquica de um empregado, ameaçando o seu emprego ou degradando o ambiente de trabalho, expondo o trabalhador a situações humilhantes e constrangedoras. Assim, estará configurado pela repetição de condutas tendentes a expor a vítima a situações incômodas ou humilhantes, com a finalidade específica de ocasionar um dano psíquico e social à vitima, marginalizando-a em seu ambiente de trabalho. Todavia, para se imputar ao empregador o dever de reparar o dano sofrido pelo empregado (que se caracteriza pelo próprio evento), a conduta culposa ou dolosa deve ser comprovada, de forma insofismável, pelo empregado (art. 186 do Código Civil).

(TRT-3 - RO: 00181201405103004 0000181-48.2014.5.03.0051, Relator: Emerson Jose Alves Lage, Primeira Turma, Data de Publicação: 18/07/2014 17/07/2014. DEJT/TRT3/Cad. Jud. Página 36. Boletim: Não.)

A matéria tem ensejado decisões díspares e contrárias àquelas com forte apelo social. As relações no ambiente de trabalho não são inertes às ocorrências externas à organização. Além disso, deve ser levada em conta a possibilidade de se verificar no cotidiano das relações laborais uma projeção de demandas afetivas oriundas das relações familiares. Essa necessidade tende a ampliar significativamente as sensações e expectativas do indivíduo em relação ao outro, potencializando comportamentos defensivos, justificadores de condutas, ou mesmo reativos, impregnando o evento pseudoassediante de impressões equivocadamente impactantes.

O indivíduo que se sente tecnicamente inferior em relação aos seus pares no ambiente de trabalho tende a superlativar as exigências do superior hierárquico ou dos colegas (clientes ou fornecedores internos), caracterizando-as como acima de suas competências e ainda, como uma ação persecutória premeditada. Essa característica ressalta a importância do componente valorativo na avaliação do caso concreto, o que talvez seja um óbice à tipificação ou definição de um formato padrão dessa modalidade de assédio, tendo em vista a subjetividade que envolve o tema e atores em torno do fenômeno. Esse entendimento assenta-se na ideia de que o direito decorre de um processo cultural, de cunho regulatório e, em alguns níveis, emancipatório.

A operacionalização do processo cultural do qual o fato emerge constitui fator essencial e desafiante na interpretação do caso concreto, reclamando análise criteriosa do plano fático. Por seu turno, é mister fixar referências mais objetivas, parâmetros de análise mínimos e norteadores de enquadramento da prática.

Quanto à complexidade do fenômeno, deve-se levar em consideração o alto grau de subjetividade e o elevado nível de abstração valorativa que envolve o conceito de dignidade humana, o qual pode ser entendido de modo díspar em relação à lógica reinante.

A excessiva tipificação, por sua vez, pode induzir a juízos dissonantes da realidade, estabelecendo limites que repercutem no processo interpretativo, de singular significado para a análise de situações jurídicas. De fato, uma rígida padronização pode conduzir a juízos de valor simplistas, produzindo vícios de avaliação ou vieses. O motivo pode ensejar uma justa alegação de assédio moral, mas é necessário compor adequadamente o conjunto fático-probatório, exortando-se adequada contextualização.

Foram analisados 30 situações (processos jurídicos) de assédio moral corporativo, cujos motivos e alegações mais frequentemente apresentados foram: 
- divulgação da lista de empregados com baixa produtividade por célula/ilha;

- ameaça de desligamento em razão da produtividade abaixo das metas;

- demonstração explícita de repulsa, com expressões não apropriadas, chulas, de baixo calão;

- ações persecutórias;

- rigor desmedido;

- situação atentatória contra a dignidade do trabalhador, a exemplo de acusações de furto;

- excessos cometidos na investigação de irregularidades;

- aplicação de sanções sem respaldo fático, investigativo e fundamento jurídico (impedimento de ascensão na carreira, de participação de processos seletivos internos e de programas internos de incentivo intelectual, transferências injustificadas, tratamento diferenciado, perda de função e suspensão, entre outras);

- delegação de tarefas cuja execução é pouco provável ou impossível;

- sabotagem de rotinas visando recriminar o assediado;

- exclusão social pelos pares no ambiente laboral, incitada ou não pela gerência;

- manipulação de avaliações periódicas funcionais (por meio de filtragem de comentários);

- uso de rótulos pejorativos (alcunhas); e

- imputação injusta de responsabilidade.

A presunção comum nas situações jurídicas analisadas foi a desestabilização emocional; efeito colidente com valores subjetivos caros à pessoa, supostamente vítima.

O confronto das argumentações, na apreciação do caso concreto, revelaram entendimentos em rota de colisão, mesmo invocando pressupostos constitucionais: o poder de proteção à propriedade no exercício da atividade econômica e a preservação da dignidade humana.

O poder diretivo do empregador, polo da assimetria poder-dever, apesar de legalmente reconhecido, não deve apresentar-se invasivo em relação à liberdade, moral, honra, crença, intimidade e demais valores subjetivos do empregado, elementos que definem o que se denomina de dignidade humana (bem tutelado pelo direito). O exercício desse poder prevê as funções de organização, coordenação, delegação, regulamentação, disciplina e fiscalização, uma vez que sobre o empregador recai o risco do empreendimento. Assim, as ações gerenciais circunscritas por esse escopo são resguardadas pela Lei, adstringindo-se, igualmente, às disposições contratuais.

O exame das argumentações denuncia que os tribunais compartilham o entendimento de que o genuíno poder disciplinar não exorbita os limites impostos pelas normas organizacionais lícitas (explícitas ou não), muito menos, implica sujeição da pessoa àquela do empregador por meio de privação das liberdades. No plano do "ser" (existencial), aquele substantivo, o reconhecimento valorativo da dignidade humana é a amálgama que equilibra e harmoniza as dualidades das relações sociais.

De fato, o fenômeno jurídico objeto desse estudo evidencia a impossibilidade de analisá-lo e compreende-lo sem lançar um olhar para os pressupostos que alicerçam a concepção da dignidade humana: liberdade, coexistência social e solidariedade. "A dignidade da pessoa humana é o epicentro das normas constitucionais, o sustentáculo dos direitos fundamentais e a base dos direitos de personalidade" (MENEZES, 2008, p. 119). 
Caracterizar a prática assediante no âmbito organizacional, ou fora dele, visita dimensões de análise subjetivas, o que reclama ponderação na formação de juízo de valor. $O$ homem se insere numa contextualidade social, o que torna as decisões iniciativas dotadas de complexidade singular.

É inequívoco que o assédio moral vulnera o espaço de expressão e decisão do indivíduo, comprometendo sua autoestima, liberdade e senso de autopreservação e pertencimento àquele grupo social. As narrativas analisadas apontam nessa direção.

A dignidade representa um espaço invisivelmente delimitado, preenchido por valores e crenças. Nesse espaço, o indivíduo é livre para ser e estar, num exercício pleno de personalidade, tutelado juridicamente.

Em face do exposto, as decisões revelaram cautela dos magistrados na avaliação da configuração do assédio moral, visando evitar a banalização do instituto e ensejar uma aproximação entre interpretação e realidade.

\section{Conclusões}

O direito do trabalho cumpre a missão social de restringir os inconvenientes decorrentes da dependência jurídica (subordinação) do empregado em relação ao seu empregador, configurada pelo exercício do poder de mando a este conferido. Esse papel dosador imprime à especialidade uma imagem com forte feição protecionista em relação ao laborista.

O contrato de trabalho não pode ser um instrumento cerceador dos direitos fundamentais. Em face do exposto, o ordenamento oferece tutela à personalidade e cidadania. $\mathrm{O}$ assédio moral, do ponto de vista jurídico, consiste numa violação de deveres contratuais, além de desrespeito aos princípios da dignidade e da boa-fé. É caracterizado por condutas antiéticas prolongadas e materializadas por meios variados (gestos, postagens nas redes sociais, e-mails, palavras e outros escritos com teor constrangedor, vexatório e inapropriado), visando instabilizar, discriminar, humilhar, denegrir (imagem), excluir (socialmente), cercear liberdades, censurar.

Prática despojada de valoração moral, o assédio moral corporativo atinge, além da vítima (o trabalhador), famílias e pessoas próximas, podendo tornar-se o gatilho que catalisa comportamentos sociais violentos. Isso amplia significativamente o alcance social do problema e chama atenção para a relevância do tema.

Essa revisão de literatura aponta para uma caracterização imprecisa do assédio moral, dificultando sua configuração aplicada ao caso concreto. $\mathrm{O}$ conceito agrupa diferentes formas de assédio.

O assédio organizacional é tratado como assédio moral, quando na verdade não o é em essência, tendo em vista que grande parte das ocorrências atende às demandas dos modelos de produção baseados no capital. Entende-se que as definições devem tocar a natureza do objeto definido e não, meramente, as consequências. O assédio organizacional (ou corporativo) pode ter consequências morais e não ser necessariamente moral, uma vez que a pessoalidade e intenção dirigida são afastadas. O assédio exclusivamente corporativo é apessoal.

A partir dessa revisão e da análise das situações jurídicas, são elencados como fatores-chave da prática: o dolo (intenção dirigida a alguém ou grupo), a pessoalidade, o objetivo lesivo, a premeditação (planejamento), a processualidade e a lesão ou dano decorrente.

Neste artigo, defende-se que o fenômeno pode decorrer da colisão de interesses de grupos identitários. Esses embates ultrapassam os limites da mera divergência, alcançando o patamar de conflitos improdutivos.

O conflito é útil aos propósitos organizacionais quando provoca reflexão, discussão, mudança de atitude e realinhamento de objetivos (conflito produtivo). Os conflitos improdutivos emergem de diferenças irreconciliáveis que, gerenciadas inadequadamente, culminam em confrontos desregrados e amorais. 
Este estudo enfatizou a relevância de se compreender o problema e mitigá-lo, trazendo à discussão as diferentes visões concernentes ao tema, ressignificando a caracterização do assédio moral.

Percebe-se que as perspectivas do assediado e assediador não mais bastam à análise do problema. Essa dialética simplificadora exclui outros atores do processo, igualmente relevantes. A conivência, ativa ou passiva, é corresponsável pelo assentamento cultural dessa violência, cristalizando crenças e valores cerceadores da liberdade do indivíduo. Compartilhados no estrato social, esses elementos são utilizados para justificar e perpetuar a conduta abusiva, enraizando a indiferença e a banalização dos ataques à dignidade.

A análise empreendida, por meio da revisão da literatura sobre o tema e de casos, lança uma reflexão pertinente sobre o sentido e o alcance do conceito de dignidade humana e solidariedade social. A pesquisa aponta para um conceito de dignidade que, embora subjetivo, é preenchido por sentidos, crenças, convicções e valores morais; elementos que alicerçam a intimidade, honra e imagem do indivíduo, direitos de personalidade tulelados pelo sistema jurídico brasileiro.

Dessa perspectiva, qualquer iniciativa de invasão desse "espaço" (patrimônio intangível) representa inequívoca violação desses direitos, a qual, acompanhada dos elementos dolo, pessoalidade, objetivo lesivo, premeditação, processualidade e dano decorrente, configura objetivamente o assédio moral.

O esforço dos juristas em contextualizar visa compensar essa imprecisão conceitual.

Por essa razão, estudos sobre assédio moral importam à sociedade posto que incorporam novas leituras e impressões acerca do tema, ensejando um direcionamento mais eficaz à elaboração de possíveis estratégias de prevenção.

Embora se reconheça a relevância dos efeitos causados à pessoa, a revisão de literatura demonstra pouca ênfase na solução do problema, talvez, pela emergência de criminalização em nível federal.

A psiquiatrização da vítima restringe o universo de soluções preventivas e corretivas possíveis. Assim, tornase urgente que sejam exploradas experiências de recuperação, pois grande parte dos trabalhos se limita às consequências, não se estendendo ao campo da terapêutica. O ponto de convergência das diferentes abordagens sobre o tema fica restrito ao entendimento de que a repercussão social do assédio moral é um problema de saúde pública.

É ponto pacífico entre os operadores do direito, jurisprudência nacional e doutrina, o reconhecimento dos direitos humanos nas relações de trabalho, o que o coloca sob eficácia imediata.

As situações de assédio comunicam o esvaziamento do sentido da moralidade, pertencimento e da dignidade social, em nome de interesses individualistas desenvolvidos a partir da concepção de competitividade.

O estudo, ainda embrionário, colocou em contraste a necessidade de contextualização do fato propulsor da denúncia, tendo em vista que não se pode olvidar a relevância do significado ou sentido atribuído pelo indivíduo ao fenômeno analisado.

O tema segue fecundo para a realização de pesquisas sob novos recortes e perspectivas, quadro que aquiesce a discussão, tendendo a evoluir para uma intervenção social concreta e eficaz. Afinal, "Os pensamentos, ideias, propostas importam se puderem se realizar e se puderem de alguma maneira nos afetar e nos atingir" (JAMES, 1979).

O tema reclama pragmatismo na abordagem.

A relação laboral é um elemento crucial ao desenvolvimento de uma nação, tanto do ponto de vista econômico como social. 


\section{Referências}

ALKIMIN, M. A. Assédio moral na relação de trabalho. Curitiba: Juruá Editora, 2013. 15-19 p.

ALVARENGA, R. Z. Direitos da personalidade do trabalhador e poder empregatício. São Paulo: LTR, 2013. 22-23 p.

ANTlOGA, C. S. X.; COSTA, S. H. B. Organização do trabalho e o prazer-sofrimento dos trabalhadores de uma empresa familiar de vendas. In: MENDES, A. M. (Org.). Psicodinâmica do trabalho: teoria, método e pesquisa. São Paulo: Casa do Psicólogo, 2007. 195 p.

ARGIMON, I. I. L.; GAUER, G. J. C.; OLIVEIRA, M. S. Bioética e psicologia. Porto Alegre: EDIPUCRS, 2009. 79$80 \mathrm{p}$.

BARRETO, M. Violência, saúde, trabalho: uma jornada de humilhações. São Paulo: EDUC; FAPESP, 2003.

BRASIL. Decreto-lei no 5.452, de $1^{\circ}$ de maio de 1943. Consolidação das leis do trabalho. Brasília, DF, 1943.

BRASIL. Lei no 10.406, de 10 de janeiro de 2002. Código Civil brasileiro. Brasília, DF, 2002.

BRASIL - Tribunal Regional do Trabalho - 3 - RO: 00181201405103004 0000181-48.2014.5.03.0051, Relator: Emerson José Alves Lage. Primeira Turma. Data de Publicação: 18 jul. 2014 / 17 jul. 2014. DEJT/TRT3/Cad. Jud. Página 36.

BUSSINGUER,M. A. Liberdade e dignidade em Kant e o princípio da dignidade humana como fundamento do direito do trabalho. Revista de Direitos e Garantias Fundamentais, Vitória, n. 4, p. 121-146, jul./dez. 2008.

CAICEDO, M. C. El daño extrapatrimonialemela coso laboral: extensión del daño como fuente de la responsabilidad civil del empleador. Colombia: U. Externado de Colombia, 2012.

CASTRO, C. R. C. O que você precisa saber sobre assédio moral nas relações de emprego: doutrina, jurisprudência e casos concretos atuais. São Paulo: LTR, 2014. 17-31 p.

CROMBERG, R. U. Paranoia: clínica psicanalítica. São Paulo: Casa do Psicólogo, 2001. 25-26 p.

CUNICO, M. M. Saindo do silêncio: o assédio moral quase destruiu minha vida. Curitiba: Cunico, 2014. 9-18 p.

DALLENGRAVE JÚNIOR, J. A. Assédio sexual e moral: conceito e alcance. In: DANTAS JÚNIOR, A. R. et al. Direito individual do trabalho. Curitiba, PR: IESDE Brasil, 2012. 437-440 p.

DAYNES, K.; FELlOWES, J. Como identificar um psicopata: cuidado! Ele pode estar mais perto do que você imagina. São Paulo: Cultrix, 2012, capítulos 1, 2 e 3.

DINIZ, M. A. V. Estado social e princípio da solidariedade. Revista de Direitos e Garantias Fundamentais. Vitória, n. 3, p. 31-48, jul./dez. 2008.

DONOSO, D. F. M. O direito à identidade pessoal e a atualidade do pensamento de Carlos Fernandéz Sessarego. In: VILlatore, M. A. C.; ALMEIDA, R. S. (Orgs.). As aplicações do Direito de personalidade ao Direito do Trabalho: questões polêmicas e soluções políticas. Curitiba: Juruá Editora, 2013. 33-54 p.

DORFMAN, S. et al. Transtorno de personalidade narcisista. In: CATALDO NETO A.; GAUER, G. J. C.; FURTADO, N. R. (Orgs.). Psiquiatria para estudantes de medicina. Porto Alegre: EDIPUCRS, 2003. 609-612 p.

DUFFY, M.; SPERRY, L. Mobbing: causes, consequences and solutions. Inglaterra: Oxford University Press, 2012.1 $22 \mathrm{p}$.

EINARSEN, S. The nature, causes and consequences of bullying at work: the Norwegian experience. Perspectives Interdisciplinaires Sur le Travail et la Santé, v. 7, n. 3, 2005.

FAGUNDES, T. C. P. C. Metodologia da pesquisa. Salvador: UNEB/EAD, 2009. 21 p. 
FERNANDES, M. M. Os limites à subordinação jurídica do trabalhador: em especial ao dever de obediência. Lisboa: Quid Juris, 2008. 23-24 p.

FERREIRA, J. B. et al. Situações de assédio moral a trabalhadores anistiados políticos de uma empresa pública. Psicologia em Revista, Belo Horizonte, v. 12, n. 20, p. 215-233, 2006.

FREIRE, P. A. O assédio moral como corolário dos sistemas fordista / taylorista e toyotista e os danos à saúde mental do trabalhador. Revista SJRJ, Rio de Janeiro, n. 25, p. 377-394, 2009.

FREITAS, M. E.; HELOANI, R.; BARRETO, M. Assédio moral no trabalho. São Paulo: Ed. Cengage, 2008.

GABBARD, G. O. Psiquiatria psicodinâmica na pratica clínica. Porto Alegre: Artmed, 2007. 297 p.

GARCÍA, E. F. Dignidad humana y ciudanía cosmopolita. Madrid: Editorial Dykinson, 2001. 20 p.

GUIMARÃES, L. A. M.; RIMOLI, A. O. "Mobbing" (assédio psicológico) no trabalho: uma síndrome psicossocial multidimensional. Psicologia: Teoria e Pesquisa, Brasília, v. 22, n. 2, p. 183-191, ago. 2006. Disponível em: <http://www.scielo.br/scielo.php?script=sci_arttext\&pid=S0102-37722006000200008\&lng=en\&nrm=iso>. Acesso: 15 março 2015.

HAAK, M. P.; ABAL, F. C. Dano moral coletivo decorrente da prática de dumping social. In: ABAL, F. C. (Org.).Direito do trabalho: estudos de temas atuais. Passo Fundo: UPF Editora, 2014. (Seção 3)

HILAL, A. V. G. Dimensões e clusters de cultura organizacional: de uma empresa brasileira com atuação internacional. Rio de Janeiro: Mauad, 2003. 120-134 p.

HIRIGOYEN, M. Mal-estar no trabalho: redefinindo o assédio moral. Rio de Janeiro: Bertrand Brasil, 2012. 15-93 p.

HIRIGOYEN, M. El acoso moral: el maltrato psicológico em la vida cotidiana. Barcelona: Paidós contextos, $2013 a$. $19-46 \mathrm{p}$.

HIRIGOYEN, M. El acoso moral: distingir lo verdadeiro de lo falso Barcelona: Paidós contextos, 2013b. 11-103 p.

HIRIGOYEN, M. Todo lo que hay que saber sobre el acoso moral en el trabajo. Barcelona: Paidós Contextos, 2014. $21-44 \mathrm{p}$.

JAMES, W. Pragmatismo. São Paulo: Nova Cultural, 1979.

LEYMANN, H. Mobbing and psychological terror at workplace. Violence and Victims, v. 5, p. 119-126, 1990.

LORENTE, M. B. Mobbing: como prevenir y superar el acoso psicológico. Barcelona: Paidós Contextos, 2005.

LUQUE, A. G. El trabajo: presente y futuro. In: LUQUE, A. G. (Coord.) Sociopsicologia del trabajo. Barcelona: Editora UOC. 2006. 19-40 p.

MENEZES, J. B. A família na Constituição Federal de 1988 - uma instituição plural e atenta aos direitos de personalidade. NEJ, v. 13, n. 1, p. 119-130, jan./jun. 2008.

MERÍSIO, P. M. Noções gerais de direito e formação humanística. Rio de Janeiro: Elsevier, 2012. 163-165 p.

MORAES, A. Direitos fundamentais: teoria geral. São Paulo: Atlas, 2011, 48 p.

NEGRI, S. Mobbing: nove storiedi lavoro e ingiustizia quotidiana. Itália: Libreria Universitaria, 2011. 11-91 p.

OLIVARES, R. S. El acoso moral en el trabajo. Marid: Consejo Económico y Social, 2005. 54 p.

OLIVEIRA, A. F. Identificação organizacional. In: SIQUEIRA, M. M. M. Medidas do comportamento organizacional: ferramentas de diagnóstico e de gestão. Porto Alegre: Artmed, 2008. 178-188 p. 
PADILHA, A. C. M.; PICHLER, N. A.; FAGUNDES, P. M. Novos tempos, novos desafios, causas e consequências do assédio moral nas organizações contemporâneas. In: PICHLER, N. A.; PADILHA, A. C. M.; ROCHA, J. M. (Orgs.). Ética, negócios \& pessoas. Jaguarão, RS: Editora Unipampa, 2011. 94-105 p.

PAZ, M. G. T.; NEIVA, E. R. Configurações do poder. In: SIQUEIRA, M. M. M.. Novas medidas do comportamento organizacional: ferramentas de diagnóstico e de gestão. Porto Alegre: Artmed, 2014. 104-122 p.

RIGOLIN, A.; CAMARGO, D. A. Dano moral e dano psíquico no trabalho. In: GUIMARÃES, L. A. M.; GRUBITS, S. (Orgs.). Série saúde mental e trabalho. São Paulo: Casa do psicólogo, 2004. v. 3. 281-298 p.

RODRIGUES, M. Categorias de assédio moral no ambiente organizacional: uma proposta de análise. In: ANAIS ENCONTRO DA ANPAD, 2009, São Paulo.

ROJO, J. V.; CERVERA, A. M. Mobbing o acoso laboral. Madrid: Editorial Tébar, 2005. 21-60 p.

ROSS, G. A. Relaciones tóxicas: acoso, malos tratos y mobbing. Pamplona: Ediciones Enate, 2013.

RUFINO, R. C. P. Assédio moral no âmbito da empresa. São Paulo: LTR, 2011. 13 p.

SÁNCHEZ, L. J. R. Mobbing: terrorismo psicológico em eltrabajo. Madrid: Entrelíneas editores, 2003. 12-83 p.

SANTANDER, A. C. Violencia Silenciosa En La Escuela/ Silence Violence in the School: Dinamica del acoso escolar y laboral. Buenos Aires: Bonum, 2007. 105-122 p.

SCHLINDWEIN, V. L. D. C. Histórias de vida marcadas por humilhação, assédio moral e adoecimento no trabalho. Psicologia \& Sociedade, v.25, n. 2, p. 430-439, 2013.

SILVA, D. M. P. Psicologia jurídica no processo civil brasileiro: a interface da psicologia jurídica no processo civil brasileiro. São Paulo: Casa do Psicólogo, 2003. 123-133 p.

SIMM, Z. Acosso psíquico no ambiente de trabalho: manifestações, efeitos, prevenção e reparação. Rio de Janeiro: Editora LTR, 2008. 123-127 p.

SOSSELA, M. L.; NEVES, E. B. As consequências do assédio moral para trabalhadores, organização e governo. Revista Uniandrade, v. 12, n. 1, p. 17-30, 2011.

SROUR, R. H. Poder, cultura e ética nas organizações. São Paulo: Elsevier editora, 2012. 97-98 p.

THOME, C. F. O assédio moral nas relações de emprego. In: SEGOVIA, A. M. et al. (Orgs.). Direito individual do trabalho. São Paulo: Elsevier, 2011. 219-238 p.

TOZONI-REIS, M. F.C. Metodologia da pesquisa. Curitiba: IESDE Brasil S.A., 2009. 15-36 p.

VEIGA, J. M. F. Aspectos formales materiales del acoso laboral y de la violência de género e intrafamiliar. Espanha: Editorial Club Universitario, 2011.

VILELLA, F. G. Manual de direito do trabalho. São Paulo: Elsevier Editora, 2012. 152-155 p.

WYZYKOWSKI, A.; BARROS, R. C. L. G.; PAMPLONA FILHO, R. Assédio moral laboral e direitos fundamentais. São Paulo: LTR, 2014. 19-21 p.

ZABALA, I. P. Mobbing: como sobreviver ao assédio psicológico no trabalho. São Paulo: Edições Loyola, 2001. p. 30-266.

ZABALA, I. P. Mi jefe es um psicopata: por qué la gente normal se vuelve perversa al alcanzar el poder. Espanha: Alienta Editorial, 2008a. 19-25 p.

ZABALA, I. P. Mobbing, estado de la cuestión. Barcelona: Ediciones Gestión 2000, 2008b. 7-54 p. 